\title{
Divina magistra logica. Bartłomiej Keckermann jako historyk logiki
}

\author{
Regina ingenii logica est, pretiosius auro \\ ingenium, ingenio stat sine morte decus. \\ Subiacet ingenio caelum, caelo omnia subsunt. \\ Et quicquid logica celsius esse queat? \\ Logika jest królową umysłu, cenniejszy \\ od złota umysł, wieczna dzięki niemu chwała. \\ Umysłowi podlega niebo, niebu wszystko \\ podlega — cóż być może od logiki wyższe?1
}

1 Epigramat ten przytacza Keckermann w rozprawie Praecognitorum logicorum tractatus III. cum dispositione typica systematis logici adornati, Hanoviae, apud Guilielmum Antonium, 1606, s. 59 (korzystam z egzemplarza przechowywanego w Bibl. Jagiellońskiej, sygn. 585836 I). Został on zaczerpnięty z traktatu Owena Günthera (Ovenus Guntherus, 1532-1615; uczeń Melanchtona i od 1570 roku profesor logiki na Uniwersytecie w Jenie) pod tytułem Methodorum tractatus duo, continentes totius artis logicae medullam (Helmaestadii 1586). Czterowersowy epigramat składa się z dwóch rozumowań, z których każde prowadzi do uznania logiki za najważniejszą dyscyplinę, gwarantującą poznanie niezmiennych i uniwersalnych zasad rządzących rzeczywistością. Pierwsze wnioskowanie odwołuje się do dwóch, ściśle ze sobą związanych, toposów. Sentencjonalna formuła ars auro prior (upowszechniona m.in. przez L. B. Albertiego i stanowiąca skróconą wersję inskrypcji ars auro gemmisque prior, „sztuka cenniejsza niż złoto i [drogocenne] kamienie") występuje tutaj pod postacią frazy pretiocius auro ingenium. Łączy się ona z czytelnym cytatem z elegii Propercjusza (El. III. 2. 26) „ingenio stat sine morte decus” („sława zdobyta dzięki talentowi jest wieczna”). Jeśli logika jest królową umysłu, a on jest cenniejszy od złota i jako jedyny gwarantuje zdobycie sławy, to i ona posiada identyczną, jeśli nie większą, wartość. I drugie rozumowanie: jeśli wyższe ponad wszystko niebiosa podlegają umysłowi, to i rządząca nim 
Karta tytułowa rozprawy Bartłomieja Keckermanna Praecognitorum logicorum tractatus III. cum dispositione typica systematis logici adornati informuje czytelnika, że oto trzyma w swoich rękach trzecie ${ }^{2}$ wydanie traktatu, przejrzane i poprawione przez autora („nunc tertia editione recogniti atque emendati”). Nie ulega wątpliwości, że spośród wszystkich dzieł gdańszczanina owo wprowadzenie do logiki (wraz z późniejszym traktatem Systema logicae) cieszyło się, skądinąd całkiem zasłużenie, podwójnym zainteresowaniem, a mianowicie samego humanisty, który starannie je przeglądał, skrupulatnie nanosił nowe poprawki i wprowadzał niezbędne uzupełnienia za każdym razem, gdy się ukazywało, a także czytelników, wśród których szczególne miejsce zajmowali studenci filozofii jako bezpośredni adresaci traktatu, czerpiący z niego podstawowe wiadomości dotyczące logiki, jej przedmiotu, metody oraz historii. Podręcznik ten pełnił funkcję swoistego „elementarza” w nauczaniu sztuki poprawnego rozumowania i wnioskowania, a jego znajomość umożliwiała opanowanie pełnego kursu logiki (od omówienia jej podstawowych pojęć do przedstawienia zasad konstruowania sylogizmów), wyłożonego przez Keckermanna w obszernym traktacie, który ukazał się pod charakterystycznym tytułem Systema logicae, tribus libris adornatum, pleniore praeceptorum methodo et commentariis scriptis ad praeceptorum illustrationem (Hanau 1600, II wyd. Gdańsk 1605). Przedstawiając zbiór najważniejszych informacji dotyczących logiki, gdański humanista zdecydował się na zarysowanie dziejów dyscypliny, która stanowi przedmiot jego rozważań wstępnych (praecognita). Termin praecognitum ${ }^{3}$, kluczowy dla sposobu uporządkowania wykładu dziedziny przedmiotowej danej dyscypliny przez twórcę omawianego wprowadzenia do logiki, należy rozumieć jako prae-cognitum, aby podkreślić aspekt czasowy, na jaki wskazuje prefiks prae- w znaczeniu

logika wszystko przewyższa. Jeśli nie zaznaczono inaczej, wszystkie przekłady tekstów źródłowych pochodzą od Autora artykułu.

2 W rzeczywistości była to druga edycja tego traktatu (pierwsze wydanie: Hanau 1599). List Keckermanna do jego zaufanego wydawcy i przyjaciela z Hanau, Wilhelma Antoniusa (z 26 VIII 1603 roku), który został przedrukowany na samym początku traktatu, nie jest związany z kolejną (druga) edycją rozprawy z 1603 roku (jej trzecie wydanie miało faktycznie miejsce w 1613 roku). Por. J. S. Freedmann, The Career and Writings od Bartholomew Keckermann (d. 1609), „Proceedings of the American Philosophical Society", 1977, 143, s. 305-364.

3 Zob. D. Facca, Barttomiej Keckermann i filozofia, Warszawa 2005, s. 27-29. 
'przed czymś. Stąd modyfikacja semantyczna tego pojęcia, które nie oznacza doskonałej znajomości danej dyscypliny (ta bowiem możliwa jest dopiero po uważnym zapoznaniu się z wykładem systematycznym, a więc metodycznym i dotyczącym całości danej ars), ale odnosi się do "przed-pojęc" ${ }^{4}$, wyróżnionych i omówionych w czasie rozważań, które posiadają charakter wprowadzenia, a zatem rozmyślań wstępnych przed przystąpieniem do tych właściwych, to znaczy przynależących strukturalnie do systema.

Wyjaśnienie wybranych kwestii szczegółowych związanych z podjętą przez Keckermanna rekonstrukcją historii logiki ${ }^{5}$ (niemal cały rozdział drugi traktatu zatytułowany został De logicae disciplinae inventoribus et auctoribus ab initio mundi ad hunc usque editorum Praecognitoram annum $^{6}$ ) jest celem niniejszego artykułu. Poglądowe ujęcie tego zagadnienia przedstawił już w monografii gdańszczanina Bronisław Nadolski ${ }^{7}$, który sporządził także wykaz autorów najważniejszych traktatów logicznych z szesnastego stulecia, przywoływanych przez twórcę Praecognitorum logicorum tractatus... Postaram się tę rekonstrukcję uzupełnić o miejsca całkowicie pominięte albo opatrzone przez Nadolskiego lapidarnym i często niewystarczającym komentarzem. Z uwagi na złożoność i rozległość zagadnienia polemiki Keckermanna z koncepcją logiki Piotra Ramusa i jego zwolenników ${ }^{8}$, kwestię tę celowo odsuwam

4 Por. ibidem, s. 27-28. Praecognita stanowią część znacznie bardziej rozbudowanej koncepcji metodologicznej Keckermanna, która zakłada, że poznawanie danej dyscypliny organizuje triadyczny schemat: praecognita, systemata (w tym porządku występują praecepta $\mathrm{w}$ przypadku nauk teoretycznych i canones $\mathrm{w}$ przypadku dyscyplin praktycznych) oraz gymnasia.

5 Por. C. Vasoli, Bartholomeus Keckermann e la storia della logica, w: La storia della Filosofia come sapere critico. Studi offerti a Mario Dal Pra, ed. E. Garin, Milano 1984, s. 240-259; Id., Logica ed 'enciclopedia' nella cultura tedesca del tardo Cinquecento e del primo Seicento: Bartholomaeus Keckermann, w: Atti del Convegno Internazionale di Storia della Logica, San Gimignano, 4-8 dicembre 1982, ed. V. M. Abrusci, E. Casari, M. Mugnai, Bologna 1983, s. 97-116.

6 Por. „index tractatuum: primus tractat de natura logicae; secundus habet historiam logicam ab initio mundi ad currentem usque annum, ubi simul de Rameae institutionis proprietatibus disquiritur; tertius agit de logici systematis partitione ac recta conformatione" (Praecognitorum logicorum..., s. 2, k. Av).

7 Por. B. Nadolski, Życie i dziatalność naukowa uczonego gdańskiego Barttomieja Keckermanna. Studium z dziejów Odrodzenia na Pomorzu, Toruń 1961, s. 36-50.

8 Kwestię tę podejmuje Keckermann dwukrotnie w omawianym traktacie. Por. Dissertatio ad logicae studiosos de Logicorum Praecognitorum instituto, deque contro- 
nieco na plan dalszy, ale w żadnym wypadku nie usuwam jej całkowicie w cień. Zamiast prezentacji próby w miarę pełnego odtworzenia diachronicznego ujęcia ars ratiocinandi, opracowanego przez gdańskiego humanistę, spróbuję przedstawić znamienne dla niego sposoby myślenia o logice, w tym także o jej dziejach. $Z$ tego powodu omawiając czasy współczesne Keckermannowi, wybieram tych autorów, którzy odegrali największą rolę w powstaniu i ukształtowaniu się jego teorii logicznej, wyrastającej w prostej linii z sylogistyki Arystotelesa, co wcale nie oznacza, że lista tych twórców ogranicza się do grona komentatorów Stagiryty. Proponuję wobec tego praecognita w kwestii Keckermannowej logiki i jej historii.

Dyskursy logiki

Praecognita w ujęciu Keckermanna posiadają charakter wstępnego rozpoznania danej dziedziny. Nie tylko zapoznają one ucznia z zestawem jej podstawowych pojęć, lecz także wskazują autorów uznanych za ważnych dla omawianej dyscypliny, przedstawiając czasem całkiem pokaźną listę lektur zalecanych. Ów index librorum commendatorum stanowił niezbędny element humanistycznych traktatów de ratione studii ${ }^{\circ}$, dotyczących opracowania wzorcowego w przekonaniu ich autorów pro-

versiis inter philosophos Peripateticos et Rameos, s. 6-39 (wraz z częścią zatytułowaną Controversiae generales principales de rebus ipsis et earum in disciplinis traditione, seu

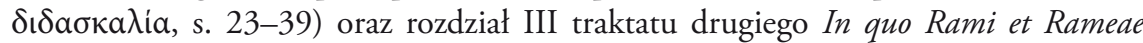
disciplinae proprietates percensentur (s. 105-151).

9 Por. m.in. takie rozprawy jak: Erazm z Rotterdamu, De ratione studii ac legendi interpretandique auctores, libellus aureus (Paryż 1511, Kraków 1519), Peter Schade (Petrus Mosellanus), Paedologia in puerorum usum conscripta (Lipsk 1518, Kraków 1521, 1527), Krzysztof Hegendorfer (Christophorus Hegendorfinus, 1500-1540), De recta studendi et vivendi ratione ad bonarum litterarum virtutumque studiosos in Gymnasio Posnanensi adhortatio (Kraków 1530), Guillaume Budé, De philologia oraz De studio litterarum recte et commode instituendo (Bazylea 1532), Szymon Marycjusz z Pilzna, De scholis seu academiis libri duo (Kraków 1551), Stanisław Sokołowski (1537-1593), De ratione studii (powst. 1572, wyd. Kraków 1619). Zob. również: przekład wspomnianego wyżej traktatu Erazma w: Erazm z Rotterdamu, Polecany spis lektur, tłum. M. Cytowska, w: Id., Wybór pism, oprac. M. Cytowska, Wrocław-Kraków-Warszawa 1992 (BN II 231) oraz Sz. Marycjusz z Pilzna, O szkotach czyli akademiach ksiag dwoje, przeł. A. Danysz, wstęp i objaśnienia H. Barycz, Wrocław 1955; B. Roest, Rhetoric of Innovation and Recourse to Tradition in Humanist Pedagogical Discourse, w: Medieval and Renaissance Humanism: Rhetoric, Representation and Reform, ed. S. Gersh, B. Roest, Leiden 2003, s. 115-148. 
gramu studiów. Bronisław Nadolski zauważa ${ }^{10}$, że na polu historiografii logicznej wyprzedził Keckermanna jedynie Piotr Ramus jako autor krytycznego komentarza do pism logicznych Arystotelesa Scholarum dialecticarum, seu animadversionum in Organum Aristotelis libri viginti (Francofurti 1581) ${ }^{11}$. Trzeba tutaj przypomnieć, że Ramus ogłosił we wrześniu („mense septembri”) ${ }^{12} 1543$ roku w Paryżu traktat Dialecticae partitiones, sive institutiones, w którym przedstawił zarys kontrowersyjnego programu reformy nauczania logiki (próba określenia na nowo statusu dialektyki jako autonomicznej dyscypliny — „dialectica virtus est disserendi” ${ }^{13}$. W tym samym czasie opublikował drugą rozprawę ${ }^{14}$, Aristotelicae animadversiones (stała się ona zalążkiem systematycznie uzupełnianego i rozwijanego komentarza Scholarum dialecticarum ${ }^{15}$,

10 Zob. B. Nadolski 1961, s. 37-38.

11 Por. L. D. Green, J. J. Murphy, Renaissance rhetoric short title catalogue, 1460 1700, Aldershot 2006, s. 363-364; Ch. H. Lohr, Latin Aristotle Commentaries: Renaissance Authors, Firenze 1988, s. 374.

12 Por. Ch. Waddington, Ramus: sa vie, ses écrits et ses opinions, Paris 1855, s. $442-444$.

13 Zob. W. J. Ong, Ramus, method, and the decay of dialogue: from the art of discourse to the art of reason, third ed., Chicago 2004, s. 173-193; P. Sharratt, Peter Ramus, Walter Ong, and the Tradition of Humanistic Learning, „Oral Tradition” 2/1 (1987), s. 172-187; H. Hotson, Commonplace learning: Ramism and its German ramifications, 1543-1630, Oxford 2007, s. 43-45.

14 Paryski wydawca Ramusa, Jacques Bogard (Iacobus Bogardus), ogłosił obie rozprawy w jednym tomie. 10 III 1544 roku ukazał się specjalny edykt królewski Franciszka I, który wprowadzał całkowity zakaz ich dalszej publikacji. Kontrowersyjne poglądy Ramusa spotkały się ponadto z natychmiastową odpowiedzią francuskich humanistów związanych z arystotelizmem: filozofa, matematyka i nadwornego medyka Karola IX, Jacquesa Charpentiera (Iacobus Carpentarius, 1524-1574) i benedyktyna Joachima Périona (Ioachimus Perionus, ok. 1499-1559).

15 Por. J. V. Skalnik, Ramus and reform: university and church at the end of Renaissance, Kirksville 2002, s. 41-44. Autor studium zwraca uwagę na ciekawą koincydencję istotnych z punktu widzenia rozwoju nauki zdarzeń, które miały miejsce w 1543 roku. Ukazało się wówczas słynne dzieło Mikołaja Kopernika De revolutionibus orbium caelestium, a Andre Wesale (Andreas Vesalius, 1514-1564), zwany „księciem anatomii”, opublikował traktat De humani corporis fabrica. Makrokosmos (heliocentryczna teoria wszechświata) oraz mikrokosmos (kompletny opis budowy anatomicznej człowieka) zostały zatem wyczerpująco opisane dokładnie w tym samym czasie. Wszystkie trzy dzieła łączy z pewnością jedna rzecz — śmiałość głoszonych tez, zmuszających do krytycznej rewizji podstawowych założeń obowiązującego powszechnie światopoglądu, wzbudzała liczne kontrowersje i niekończące się polemiki. 
w której próbował wytłumaczyć, dlaczego uznał przeprowadzenie takiej reformy za konieczne. Dość powiedzieć, że lektura pism Stagiryty doprowadzić go miała do wniosku o braku przejrzyście wyłożonej metody u Arystotelesa, by ukazać śmiałość ataku młodego uczonego na uświęcony wielowiekową tradycją autorytet. Jak stwierdza James Jerome Murphy ${ }^{16}$, określeniami szczególnie preferowanymi przez Ramusa stały się tenebrae (a więc 'ciemności', 'zaślepienie', 'niejasność') oraz epitet miser ('żałosny', 'głupi', 'niedorzeczny'), używany w odniesieniu do autora Metafizyki. Nawiązania do pism innych logików posiadają tutaj charakter jedynie egzemplaryczny, ponieważ poszukiwaniu wspólników w krytyce Stagiryty, i nie tworzą, jak to ma miejsce u Keckermanna, spójnej narracji historycznej, ujmującej dzieje logiki w postaci chronologicznej sekwencji wystąpień poszczególnych logików, którzy odegrali znaczącą rolę w jej rozwoju. Historia dialektyki, gdyż takim pojęciem posługuje się najczęściej Ramus na oznaczenie ars disserendi, stanowi dla niego swoiście pojmowany sedes argumentorum, z którego niemal bez ograniczeń można czerpać argumenty wspierające głoszone tezy. Nic zatem dziwnego ${ }^{17}$, że gdański humanista nie powołuje się na to dzieło Ramusa, do którego zresztą odnosi się przeważnie polemicznie, lecz przyznaje się do korzystania w trakcie pracy nad wprowadzeniem do logiki ze znanego dzieła Diogenesa Laertiosa De clarorum philosophorum vitis, dogmatibus et apophtegmatibus.

Przedstawienie historii logiki wysuwa się spośród zagadnień poruszanych przez Keckermanna w drugiej części traktatu Praecognita logica na plan pierwszy, ale w żaden sposób nie wyczerpuje w całości jego tematyki. Ograniczanie problematyki omawianej rozprawy do próby całościowego ujęcia dziejów logiki, a taką perspektywę zdaje się przyjmować Nadolski ${ }^{18}$, daje jedynie fragmentaryczne i całkowicie niekom-

16 Por. Arguments in Rhetoric Against Quintilian: Translation and Text of Peter Ramus's Rhetoricae distinctiones in Quintilianum, transl. C. Newlands, ed. J. J. Murphy, second ed., Illinois 2010, s. 14-17. Por. następujące stwierdzenie: „One favorite term for Ramus is tenebras (obscurity, gloom, shadow); another is miser (wretched, worthless). His frequent use of the rhetorical question is often ironic or sarcastic. How do we know what knowledge is, or virtue, or utility? «Because Aristotle says so» (quia Aristoteles dixit)" (ibidem, s. 15).

17 Zob. B. Nadolski, op. cit., s. 37.

18 Por. ibidem, s. 37: „Praecognita logica — to osobliwa publikacja, jedna z pierwszych historii logiki, jakie zaczęto pisać za Renesansu”. 
pletne wyobrażenie o przedmiocie tych rozważań wstępnych. Warto zaznaczyć, że posiadają one dość nietypową, jeśli wziąć pod uwagę większość traktatów gdańszczanina, kompozycję, uwarunkowaną specyfiką prowadzonego wykładu, który ma stanowić w zamierzeniu jego twórcy właściwe wprowadzenie do studiów logicznych. Główne pojęcia danej dyscypliny są tutaj wyjaśniane poprzez serię pytań i odpowiedzi, a zatem zgodnie z charakterystycznym dla scholastycznej dysputy porządkiem quaestio - responsio, przerywaną co jakiś czas ekskursami, przybierającymi niekiedy postać stosunkowo niewielkich rozpraw (taki charakter posiada chociażby przedstawienie kontrowersji między perypatetykami a ramistami). Sposób omówienia poszczególnych zagadnień wstępnych z logiki różni się zatem od tego, który zastosował Keckermann w analogicznym do Praecognita logica... traktacie, dotyczącym wprowadzenia do studiów filozoficznych (Praecognita philosophica...) ${ }^{19}$.

Przed przystąpieniem do rekonstrukcji dziejów logiki trzeba wspomnieć o podstawowych definicjach i wyjaśnieniach związanych ze sztuką rozumowania tym bardziej, że niektóre z tych pojęć pozwalają lepiej zrozumieć zaprezentowaną przez gdańskiego profesora filozofii historię logiki. Gramatyka, retoryka i poetyka są, zdaniem Keckermanna, dyscyplinami, które służą określaniu myśli i ich językowej artykulacji, ale tylko „boska mistrzyni logika” („sola illa divina magistra logica”) ${ }^{20}$, kieruje najdoskonalszym działaniem człowieka, jakim jest myślenie. Komentując zjawisko homonimii w przypadku terminu 'logika', Keckermann wyjaśnia, że może być on rozumiany w co najmniej poczwórnym sensie ${ }^{21}$. Pojęcie to bywa bowiem na ogół odnoszone do wrodzonej

19 Praecognitorum philosophicorum libri duo, naturam philosophiae explicantes et rationem eius tum docendae, tum discendae monstrantes; publicis praelectionibus propositi et cursui philosophico praemissi in Gymnasio Dantiscano, Hanoviae, apud Guilielmum Antonium 1607.

20 Por. „10. Quae disciplinae dirigunt significationem cogitationum? R.: Grammatica, rhetorica, poetica. 11. Quae vero intellectionem sive cogitationes? R.: Sola illa divina magistra logica, quae idcirco etiam ảंò toṽ $\lambda o ́ \gamma o v$, id est, ab intellectu seu ratione (nam haec aequipollent) dicta, quia dirigit istam excelentissimam hominis operationem et bene ordinat, ne aberret, non secus atque ars fabrilis manum regit in efficiundo opere" (Praecognitorum logicorum..., s. 42).

21 Por. „12. Explica has homonymias vocis logicae. R.: Faciam omnino, qua a paucis observantur. Primo significat facultatem intelligendi et ratiocinandi omnibus hominibus naturaliter insitam, fluentem ab essentia hominis, quae et logica naturalis solet vocari [...]. Secundo significat systema praeceptorum logicorum ab hoc vel illo 
każdemu człowiekowi zdolności rozumienia i rozumowania („facultas intelligendi et ratiocinandi”). Umiejętność ta wypływa z samej istoty człowieka („fluens ab essentia hominis”). Jeśli na gruncie semantyki problematykę esencjalistyczną wprowadza pytanie o definicję („czym jest x?”), to człowiek jest tutaj określony zgodnie ze słynną frazą Arystotelesa jako „zwierzę rozumne” („homo animal rationale est”). Tę logikę, którą jednostka ludzka dysponuje z racji bycia człowiekiem, Keckermann nazywa logiką naturalną (logica naturalis). Łatwo można sporządzić jej charakterystykę: intuicyjna, niesformalizowana, ograniczona do prostych schematów wnioskowania, funkcjonująca bez rozwiniętej refleksji metateoretycznej. Terminu 'logika' używa się również w znacznie węższym zakresie znaczeniowym w kontekście systemu reguł logicznych („systema praeceptorum logicorum”). Określenie 'system' funkcjonuje w tym przypadku, jak wyjaśnia Keckermann, na zasadzie metonimii typu przyczyna zamiast skutek („metonimia causae pro effectui"). Nie oznacza bowiem wprost trwałej umiejętności (habitus) nabytej dzięki pojęciowemu i praktycznemu opanowaniu zasad danej ars, ale odnosi się do zbioru ogólnych reguł („,collectio praeceptorum universalium”), które mogą zostać wykorzystane w konkretnym działaniu. Przez słowo 'logika' określamy zatem uporządkowany uprzednio system przepisów rozumowania, ale jego właściwym znaczeniem nadal pozostaje umiejętność osiągana za ich pomocą. Metonimia jako jedna z podstawowych figur wysłowienia, modi loquendi, nie zmienia istoty rzeczy, a „przesunięcie” znaczenia, które uprawomocnia, rozgrywa się przede wszystkim na poziomie słów. Keckermann na potrzeby większej przystępności swego wykładu swobodnie porzuca prosty i operujący wyłącznie zdefiniowanymi pojęciami język logiki, włączając do niego terminy z innych słowników pojęciowych (jak chociażby retoryki czy poetyki), jeśli tylko taki zabieg pomaga w wyjaśnieniu złożonych zagadnień. Trzeba dodać, że te zapożyczone pojęcia są przez niego na ogół

auctore conscriptorum, ut cum dico logica Aristotelis, Philippi, etc., quod systema etiam ars dici potest, metonimia causae pro effectui, id est, non sumendo artem pro habitu in mente iam acquisito ex praeceptis et usu, sed pro collectione praeceptorum universalium ad operandum in certa finis latitudine [...]. Tertio significat specialiter Aristoteli certam huius integri systematis partem, eam videlicet, quae est de syllogismo communi aut contingenti, ut videre est locis ante citatis. Quarto denique logica sumitur pro habitu et arte proprie dicta in mente artificis ex praeceptis et usu acquisita, ut cum dicimus hic est bonus logicus etc." (ibidem, s. 43-44). 
od razu interpretowane w kontekście kategorii logicznych, by można je było z łatwością wprowadzić w dyskurs logiczny, a przede wszystkim zachować jego terminologiczną i semantyczną spójność. Trzecie użycie słowa 'logika' odnosi się do ściśle określonej części systemu logicznego Stagiryty, która przedstawia reguły tworzenia sylogizmów. W tym ujęciu logika oznacza sylogistykę Arystotelesa. I wreszcie ostatnim kontekstem, w jakim pojawia się termin 'logika', jest umiejętność wnioskowania osiągnięta w wyniku opanowania jej reguł, zarówno w wymiarze teoretycznym, jak i praktycznym. Dzięki temu możemy powiedzieć, że „x jest dobrym logikiem”, co daje się sparafrazować do zdania o postaci: „x doskonale przyswoił sobie reguły sztuki rozumowania”. Wyróżniając kolejne znaczenia, jakie ukrywają się za polisemantycznym, jak się okazuje, terminem 'logika', Keckermann zastosował procedurę stopniowego uszczegółowienia i konkretyzacji, która pozwoliła mu na przejście od uniwersalnej zdolności posiadanej przez wszystkich przedstawicieli gatunku ludzkiego, przez abstrakcyjny system reguł logicznych, a następnie jego część w postaci sylogistyki Arystotelesa, do umiejętności pojedynczego logika, rzemieślnika biegłego w swojej sztuce.

Uporanie się z kwestią homonimii w przypadku terminu 'logika' pozwala na sformułowanie jej definicji ${ }^{22}$ :

Jest sztuką porządkowania i kierowania działaniami ludzkiego umysłu, czyli myślami człowieka, w poznaniu rzeczy. ${ }^{23}$

Tak rozumiana logika zostaje przekształcona w sprawne narzędzie poznawania rzeczywistości. Jej epistemologiczna wartość wypływa z regulowania „pracy” myśli. Wśród właściwości, jakie wynikają z samej istoty logiki, gdański profesor wymienia m.in. acumen theoreticum, a więc olbrzymi potencjał teoretyczny, oraz iudicium, czyli zdolność wydawania sądów w kwestii prawdziwości danych stwierdzeń. Logika jest "przewodnikiem w rozumowaniu” (directorium cogitationum). Tylko ona cechuje się teoretyczną i metodologiczną „,samoświadomością”,

22 Tę definicję logiki niemal w niezmienionej postaci powtórzył Keckermann w traktacie Systema logice... (Hanoviae 1600): „Logica est ars dirigendi mentem in cognitione rerum”. Cyt. za: Systema systematum..., t. II, Hanoviae 1613, s. 67.

23 „Quid ergo est logica, prout quarta significatione sumitur? R.: Est ars humani intellectus operationes, sive hominis cogitationes ordinandi et dirigendi in rerum cognitione" (Praecognitorum logicorum..., s. 44). 
gdyż umożliwia krytyczną ocenę swego pojęciowego instrumentarium, którym dysponuje $\mathrm{w}$ trakcie dowodzenia, a także pozwala na natychmiastową weryfikację swoich ustaleń. Dzięki logice, dającej szansę krytycznego odniesienia się do funkcjonalności wykorzystywanych narzędzi i procedur dowodowych, wiemy o tym, że posiadamy wiedzę na temat danej rzeczy:

Dzięki logice nie tylko wiemy, ale także wiemy w sposób odwrotny, to znaczy, wiemy o tym, że wiemy. Ktoś może bowiem [coś] wiedzieć, a zarazem nie wiedzieć, że [to] wie. Podobnie jak żeglarze, jakkolwiek trzymają się właściwego kursu, nie wiedzą o tym, jeśli nie spojrzą na swoją busolę, tak i my nie możemy wiedzieć na pewno, że wiemy, jeśli nie spojrzymy na reguły logiczne, dzięki którym wiemy. Stąd ta nieoceniona radość i przyjemność w umyśle, którą wytwarza logika, lekarka wątpliwości, czyli niepokoju umysłu. Reguły logiczne odmierzają przecież taką samą miarą myśl i ograniczają niepewny sąd, który jest wątpliwością. Wątpienie zaś jest w pewien sposób myleniem się. Stąd również stałość w prawdzie, byś z łatwością ich nie rozdzielił.. ${ }^{24}$

Charakterystyka logiki dostarcza interesujących uwag epistemologicznych, skupionych wokół problemu uświadomienia sobie faktu posiadania wiedzy na dany temat. Stąd rozróżnienie, które można zapisać w postaci dwóch zdań: 1. x wie, że y oraz 2. x wie o tym, że wie, iż y. Jeśli logika jako jedyna dyscyplina umożliwia wspięcie się na poziom metateoretyczny, to jednocześnie dzięki jej pojęciom podmiot poznający potrafi zdobyć się na krytyczny dystans wobec przeprowadzanego aktu poznawczego i ocenę jego rezultatów. Gdańszczanin zdecydowanie próbuje odsunąć wszelkie wątpliwości od ustaleń logiki, odmawiając ars dubitandi jako zaplanowanej strategii heurystycznej jakiegokolwiek udziału w odkrywaniu i ustalaniu prawdy. Wystarczy rozmyć granicę między wątpliwościami a błędem, by możliwa się stała ich identyfi-

24 „Per logicam non solum scimus, sed etiam scimus reflexive, id est, scimus nos scire, potest nam aliquis scire et nescire se scire, sicut nautae utut rectum cursum teneant, non sciunt nisi respiciendo ad suam pyxidem, ita nos non possumus certo scire nos scire, nisi respiciendo ad normas logicas, per quas scimus. Hinc illa inaestimabilis in intellectu laetitia et voluptas, quam generat logica dubitationum, id est, inquietudinis animi medicatrix. Logicae nam normae mentem vero commensurant et determinant pendulum assensum, qui est dubitatio; dubitare autem quodammodo errare est. Unde etiam constantia in vero, ne facile seducaris" (ibidem, s. 55). 
kacja (dubitare to errare). Wątpienie wiąże się z ruchem, swobodnym przechodzeniem od jednego sądu do drugiego czy nawet zawieszeniem jednoznacznego stwierdzenia wobec faktu braku kryterium jego prawdziwości, uniemożliwiającego ostateczne rozstrzygnięcie. Tak pojmowane kwestionowanie jako element celowo wprowadzający niepewność i wątpliwości do niezmiennego, statycznego, unieruchomionego w sieci logicznych reguł świata prawdy, musi zostać od niego odsunięte. Stąd występująca tutaj symptomatyczna metaforyka medyczna, wprowadzająca osobę lekarki (w tej roli występuje oczywiście logika) i diagnozę patologicznego zaburzenia w postaci „choroby umysłu”, niepotrafiącego jednoznacznie wyrokować (iudicium).

Wszelkie rozumowanie przebiega w przekonaniu Keckermanna trójstopniowo ${ }^{25}$. Rozpoczyna się ono zazwyczaj od określenia pojedynczych terminów, zwanych przez niektórych logików tematami prostymi (np. człowiek, zwierzę). Ich połączenie w dwuelementowe zdanie wyznacza drugi stopień operacji rozumowania (np. człowiek jest zwierzęciem lub człowiek nie jest kamieniem). Jego najwyższy poziom łączy się z wykorzystywaniem wielu terminów, które w dodatku mogą występować ze sobą w rozmaitych kombinacjach o różnym stopniu złożoności. Ro-

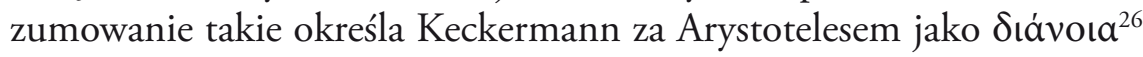
(discursus). Dyskurs oznacza w tej koncepcji, sięgającej początkami poglądów Platona, zarówno sam proces myślenia jako intelektualnego oglądu danego wycinka rzeczywistości, jak i jego zapis przy pomocy

25 Por. „9. Quot autem sunt gradus in intellectu, sive cogitationibus huminis? R.: Recte quaeris de gradibus, quia iuxta hos instrumenta et praecepta logica partiemur, neque enim intellectus noster est ita simplex, ut in certos velut grades, ordines et partes non debeat distingui. Sunt autem tres. Primus gradus est simplicissimus, nimirum apprehensio unius tantum simplicisque termini, ut animal. Dn. Philippus et alii vocant quaestionem, sive thema simplex. Alter gradus est conceptus duorum terminorum, quos cogitando inter se coordinamus, ut cum cogitamus Homo est animal, vel Homo non est lapis. Tertius gradus est, quando plures terminos coordinamus cogitando quam duos, ab uno ad aliud cogitationem moventes. Aristoteli vocatur Sı́́voı́a, Latinis discursus, qui iterum duplex est: illativus et ordinativus" (ibidem, s. 50).

${ }^{26}$ O związkach pojęć dianoia i ethos zob. M. W. Blundell, Ethos and Dianoia Reconsidered, w: Essays on Aristotle's Poetics, ed. A. O. Rorty, Princeton 1992, s. 155-176. O funkcjonowaniu terminu dianoia w teorii retorycznej Arystotelesa por. K. Eden, Hermeneutics and the Ancient Rhetorical Tradition, w: The rhetoric canon, ed. B. D. Schildgen, Detroit 1997, s. 127-151. 
określonych pojęćc ${ }^{27}$. Przyjmowane tacite założenie o istnieniu analogii, nawet jeśli jest ona niepełna, między myślą a słowem, umożliwia sprawne funkcjonowanie wieloetapowego dyskursu w obu rejestrach, konceptualnym i językowym. W praktyce może on zostać zrealizowany w dwojaki sposób, który pozostaje uzależniony od stopnia jego formalizacji i zamierzonego celu. Pierwszy rodzaj dyskursu określony jako sylogistyczny (discursus sylogisticus) ${ }^{28}$ polega na wykazywaniu słowo iudicium sugeruje intelektualną „władzę sądzenia”, przejawiająca się w wydawaniu jednoznacznych rozstrzygnięć — prawdziwości bądź fałszywości danego wniosku poprzez uważną analizę przesłanek, na podstawie których został sformułowany. Drugi rodzaj tego typu rozumowania, nazwany dyskursem metodycznym (discursus methodicus) ${ }^{29}$, wiąże się z porównywaniem jednego zagadnienia danej dyscypliny z innym, by określić (znów czasownik iudico), w jaki sposób są one ze sobą powiązane. W definicji metody, terminu kluczowego dla pojęciowego systemu Keckermanna, a także dla wczesnonowożytnych dyskusji toczonych wokół arystotelizmu ${ }^{30}$, pojawiają się frazy znane z wcześniejszych rozważań:

27 W Systema logicae Keckermann wyraża tę myśl nieco inaczej. Stwierdza bowiem, że pierwszorzędnym przedmiotem logiki jest ludzki umysł (ratio), drugorzędnym zaś - wysłowienie rozumowania (oratio): „Regit autem logica mentem nostram et eius conceptus, non absolute, sed in relatione ad res, id est quatenus actu circa res apprehendendas et iudicandas sunt occupati [...]. Quin et circa orationem seu verba versatur logica, tamquam circa secundarium suum obiectum, non quidem, qua verba sunt suis combinata litteris et syllabis, sic enim ad grammaticum pertinent, nec qua ornatu sunt decoranda, sic enim rhetoricae sunt et poeticae, sed qua mentis conceptus respiciunt, iisque aliquid significant et explicant [...]". Cyt. za: Systema systematum..., s. 68.

28 Por. „10. Quid est discursus illativus? R.: Est cogitationum nostrarum eiusmodi agitatio et motus, quo ex termini tertii cum duobus coordinatione repetita iudicamus terminorum illorum duorum coordinationem vel veram esse vel falsam. Vocatur discursus sylogisticus" (Praecognitorum logicorum..., s. 50).

29 Por. „11. Quid est discursus ordinativus? R.: Est cogitationum nostrarum motus ab una doctrinae sive tractationis parte ad alteram, ut iudicemus, quomodo partes inter se cohaereant, vocatur et discursus methodicus" (ibidem, s. 50-51).

30 Por. N. W. Gilbert, Renaissance concepts of method, New York 1960. O pojęciu metody u Keckermanna por. ibidem, s. 216-220. 
Co rozumiesz przez metodę? Nic innego, jak zbiór, czyli system wszystkich przepisów logicznych, koniecznych w trwałym przyswojeniu sobie sztuki. ${ }^{31}$

Metoda $^{32}$ jest przede wszystkim zbiorem (collectio), a więc pewnym zestawieniem elementów uporządkowanych (są nimi tutaj oczywiście poszczególne reguły logiczne) według przyjętej wcześniej zasady organizującej strukturę tego typu konstrukcji. Poza tym powinna ona uwzględniać wszystkie przepisy danej sztuki, które są niezbędne do jej opanowania. Powyższe ujęcie metody można równie dobrze nazwać statycznym, by nie powiedzieć redukcyjnym, gdyż delimitacji podlega zarówno ona sama (ogranicza się do zamkniętego zbioru reguł), jak i zakres jej funkcjonalności (jest przydatna w trakcie nauki danej dyscypliny, a jej późniejsza użyteczność staje pod znakiem zapytania). Jak rozumieć w takim razie określenie 'dyskurs metodyczny'? Czy dyskurs sylogistyczny jest w tym sensie pozbawiony metody? Czy epitety używane w kontekście rozumowania typu diávoıa (sylogistyczny - metodyczny) wzajemnie się wykluczają? Ową terminologiczną niespójność można z pewnością tłumaczyć przyjętą formułą wykładu. Praecognita... zapoznają tylko z niektórymi pojęciami i to w stopniu podstawowym, co w konsekwencji prowadzi do braku wyczerpujących omówień niektórych, niekiedy kluczowych dla poruszanej przez autora problematyki, pojęć. Próba uspójnienia pojawiających się nieścisłości możliwa jest poprzez odwołanie do traktatu Systema logicae... albo poszukiwanie wytłumaczenia dla nich wewnątrzpojęciowej siatki, zaledwie naszkicowanej w Praecognita logica... Spróbuję urzeczywistnić tę drugą możliwość. Dyskurs sylogistyczny jest oczywiście metodyczny w świetle powyższej definicji metody, ponieważ sylogistyka daje się z łatwością

31 „3. Quid intelligis per methodum? R.: Nihil aliud quam collectionem sive systema omnium praeceptorum logicorum necessariorum ad habitum artis acquirendum. 4. Quaenam circa hoc systema consideranda sunt? R.: Duo praecipue: primus eius inventio, secundo eius conformatio" (ibidem, s. 65).

32 Uwagi Keckermanna nad pojęciem metody przedstawione w Praecognita logica... stanowią zalążek znacznie bardziej rozbudowanej refleksji teoretycznej nad metodą i metodycznością poszczególnych dyscyplin, wyłożonej we fragmencie trzeciej księgi traktatu Systema logice..., zatytułowanym De methodo (por. Systema systematum..., s. 308-315). Wypracowując własną definicję metody oraz kreśląc jej typologię, gdańszczanin bardzo wyraźnie podąża za koncepcją metody przedstawioną przez J. Zabarellę w rozprawie De methodis libri quattuor (przedruk w: Id., Opera logica, Francofurti 1608, col. 133-372). Por. D. Facca, op. cit., s. 40-45. 
przedstawić w postaci systemu reguł, których poznanie umożliwia przeprowadzanie rozmaitych rozumowań w oparciu o znajomość poszczególnych sylogizmów i rządzącego nimi systemu wzajemnych zależności. Wprowadzając rozróżnienie dyskursu na sylogistyczny i metodyczny, Keckermann próbował scharakteryzować go pod kątem celu, który przyświeca za każdym razem posługującemu się nim człowiekowi. Nie wolno zapominać, że obydwa określenia są alternatywne wobec pary epitetów: illativus (dotyczący wnioskowania) — ordinativus (związany $\mathrm{z}$ uporządkowaniem). Rzeczą dominującą w rozumowaniu podporządkowanemu sylogizmom i prawom sylogistyki jest bez wątpienia wnioskowanie traktowane jako wyciąganie konkluzji salva veritate $\mathrm{z}$ prawdziwych bądź prawdopodobnych przesłanek. Dyskurs metodyczny służy więc wynajdywaniu różnego rodzaju powiązań między zagadnieniami należącymi do tej samej sztuki. Ta procedura hermeneutyczna rządzi się swoimi regułami, których zestawienie, oddzielne — rzecz jasna — dla każdej dyscypliny, tworzy podstawy dla metody. Jak już powiedziałem, przyjęta na użytek rozważań wstępnych definicja tego terminu znacznie ogranicza jego funkcjonalność. Nic więc dziwnego, że w traktacie Systema logicae... wprowadził Keckermann znacznie bardziej rozbudowaną i złożoną, dynamiczną, koncepcję metody (określa ją jako methodus artificialis), inspirowaną niewątpliwie poglądami Zabarelii ${ }^{33}$ (a także jego adwersarza, Franceska Piccolominiego) na ten temat, wiążąc ściśle ze sobą sposób postępowania badawczego z rzeczą, która stanowi jego przedmiot. Okazuje się wówczas, że to sama res podsuwa metodę ${ }^{34}$, dzięki której możliwe staje się jej poznanie. Stanowisko takie można określić jako „epistemologiczny kooperacjonizm”, gdyż poznający podmiot niemalże współpracuje z poznawanym przedmiotem we wspólnym dziele poznania. Porządek metody nie przynależy tym samym do sfery teoretycznych konstrukcji, ale jest naturalny, gdyż niejako zapisany w rzeczywistości.

33 Por. S. Kamiński, Jakuba Zabarelli metoda poznania naukowego, „Roczniki Filozoficzne" t. 19 (1971), z. 1, s. 57-72; N. Jardine, Keeping Order in the School of Padua: Jacopo Zabarella and Francesco Piccolomini on the Offices of Philosophy, w: Method and Order in Renaissance Philosophy of Nature: The Aristotle Commentary Tradition, Aldershot-Brookfield 1997, s. 183-209.

34 Zob. Sytema logicae..., s. 309: „Procesus methodi imitetur processum et ordinem naturalem rerum, progrediendo a natura prioribus et notioribus ad posteriora”. 
Powyższe uwagi na temat natury i właściwości logiki trzeba zamknąć określeniem jej celu. Metafora, powiada Keckermann ${ }^{35}$, wprowadzona zwyczajem mówców w obręb dyskursu bawi ludzki umysł („more rhetorum ludit intellectum metaphora”), jednak w przypadku definicji, które stanowią istotne narzędzie eksplikacji, jakim dysponuje omawiana ars, wszelkie wyrażenia metaforyczne, trącące dwuznacznością, a nawet czyniące z niej swój znak rozpoznawczy, powinny zostać odrzucone. Wśród zwolenników doktryny logicznej Ramusa i pozostałych reformatorów sztuki rozumowania nie brak takich, którzy, zdaniem gdańszczanina, rozmazują podstawowe cele logiki, wskazując na polisemantyczność kluczowego dla definicji tej sztuki terminu disserere, mogącego oznaczać 'wynajdywanie' (invenire), 'porządkowanie' (disponere), a także 'orzekanie' (iudicare). By przeciąć te spekulacje na temat wieloznaczności analizowanego pojęcia, Keckermann uważnie wylicza rozliczne kompetencje logiki:

Celem logiki jest dobrze definiować, oddzielać, łączyć zdania, argumentować, metodycznie porządkować, obalać fałszywe argumenty, wyjaśnione rozkładać, itd., i nic innego nie można powiedzieć od tego właściwie określonego celu. Jak bowiem z konieczności jeden jest cel, tak z konieczności jedna jest dyscyplina — oznaczać zaś wiele rzeczy, to zarazem nic nie oznaczać. ${ }^{36}$

Wszystkie z wymienionych powyżej zadań logiki można sprowadzić w gruncie rzeczy do analizy pojęć, która umożliwia ich definiowanie, porządkowanie i wyznaczanie zachodzących między nimi relacji. Jedność dyscypliny, wynikająca ze określenia jej definicji, a zatem wyznaczenia granic, w jakich funkcjonuje, warunkuje spójność wpisanego w nią celu. Przekonanie to leży u podstaw programu uporządkowania poszczegól-

35 Por. „21. Quid sentiendum de illo fine, quem ex Stoicis et Cicerone Ramus et alii neoterici assignant, nimirum bene disserere? R.: 1. More rhetorum ludit intellectum metaphora, cum in definitionibus, quae ad solum intellectum pure et non ad sensum vel appetitum pertinent, id in primis oporteat vitare, ne a re ad rem abducatur intellectus. 2. Peccat in secundam notam boni finis, quia ut sese ipsos Ramei interpretantur, disserere multa simul significat: 1. invenire, 2. disponere, 3. iudicare, perinde ergo est ac si cum nonnullis dicant [...]" (Praecognitorum logicorum..., s. 53-54).

36 „Finis logicae est bene definire, dividere, connectere enuntationes, argumentari, methodice disponere, falsa argumenta solvere, tractata resolvere, etc., quo nihil potest dici a bono fine alienius. Finis enim tam necessario unus est, quam necessario una est disciplina; multa enim significare simul est nihil significare [...]" (ibidem, s. 54). 
nych artes z uwagi na ich rodzaj (genus), przedmiot (obiectum) oraz cel (finis), opracowanego i konsekwentnie realizowanego przez Keckermanna w kolejnych rozprawach, w których omawiał dziedziny wiedzy, przechodząc zgodnie z „metodologicznymi” poglądami Arystotelesa od dyscyplin teoretycznych do praktycznych. Zwieńczeniem tego projektu była koncepcja systema systematum, postulująca stworzenie zbioru (systema) systemów każdej z rozlicznych artes, a więc powołania do istnienia niejako rządzącego nimi metasystemu, i w ten sposób uporządkowania całości dostępnej człowiekowi wiedzy. Systematyzacja materiału danej dyscypliny (przykładowo logiki czy retoryki) miała tutaj charakter analityczny (stworzenie katalogu przepisów na poziomie kategoryzowanej ars) oraz syntetyczny (klasyfikacja tego systemu sztuki z uwagi na kryteria metasystemu). „Mapowanie” ludzkiej wiedzy, zwięźle opisywane przez formułę systema systematum, stało się jednym z zalążków wczesnonowożytnej idei encyklopedyzmu ${ }^{37}$.

Ab origine mundi usque 1500

Wiemy już, czym jest i jak funkcjonuje logika w świetle traktatu Praecognita logica... Trzeba teraz zapytać o cel, dla którego Keckermann postanowił przedstawić jej dzieje. Nie przystąpił rzecz jasna do ich spisywania pod wpływem „nieumiarkowanej ciekawości” (curiositas nimia) ani „rozrzutności czasu” (prodigalitas temporis) ${ }^{38}$. Dla oznaczenia tej historii posługuje się on zasadniczo trzema określeniami, z których każde, nawet jeśli się one ze sobą w wielu miejscach splatają i krzyżują, nieco inaczej ukazuje sposób myślenia autora o naturze owej opowieści o przeszłości dyscypliny logicznej i jej funkcjach. Stosunkowo najbardziej neutralną znaczeniowo nazwą pozostaje "historia logiki” ( historia logica, właściwie „historia logiczna”), gdyż informuje jedynie o tym, że będzie to wykład prezentujący dzieje logiki. W podobnym polu semantycznym sytuuje się określenie „chronologia logiki” (chronologia logica), o wiele bardziej akcentujące porządek czasowy w rekonstrukcji tej narracji historycznej. I wreszcie trzecie ujęcie terminologiczne, „spis chronologiczny” (chro-

37 Por. H. Hotson, Johann Heinrich Alsted, 1588-1638: between Renaissance, Reformation, and Universal Reform, Oxford 2000, s. 33-34.

38 Por. „Desinam hic, benevole Lector, atque hanc chronologiam logicam consignabo, ubi prius id apud te exposuero, nulla me curiositate nimia aut temporis prodigalitate. Historiam hanc logicam texuisse, sed quattuor gravissimis causis impulsum" (Praecognitorum logicorum..., s. 168). 
nologia tabula), krzyżuje ze sobą charakterystykę temporalną w opisie danego zjawiska z założoną zwięzłością w przedstawieniu historycznej materii. Wieloznaczność słowa tabula, oznaczającego również 'mapę' czy 'obraz', otwiera szeroką perspektywę dla gry z metaforyką pisanie - szkicowanie, z której Keckermann robi oczywiście użytek.

Zwracając już wcześniej uwagę na propedeutyczny charakter wprowadzenia do logiki, niektóre z motywacji jego twórcy stają się niemal oczywiste. W historię sztuki poprawnego wnioskowania został wpisany zalecany spis lektur, uwzględniający te publikacje, które, w przekonaniu autora, odegrały znaczącą rolę w uformowaniu się doktryny logicznej. Pojawiają się wobec tego imiona tych, którzy wynaleźli lub przyczynili się do rozwoju logiki, „nauczycielki wszelkich umiejętności i dyscyplin oraz kierowniczki w posługiwaniu się ludzkimi myślami” („omnium facultatum ac disciplinarum magistram ac rectricem in usum humanarum cogitationum") ${ }^{39}$. Wykaz ten odsłania jednocześnie źródła filozoficznej myśli samego Keckermanna, odkrywa rozległość kultury humanistycznej gdańskiego profesora, a także pozwala wskazać tych autorów, którzy szczególnie wyraźnie odcisnęli swe piętno na jego intelektualnej biografii. Mówi on o tym zresztą wprost, przyznając się do przyjemności, jaką sprawiło mu nakreślenie historii logiki:

Prawdę mówiąc, chciałem także siebie napełnić jakąś miłą przyjemnością. Kiedy bowiem to napisałem, wtedy uważnie przyglądałem się najdoskonalszym umysłom i mistrzom ludzkich myśli, naszkicowanym tego rodzaju barwami na

39 Por. „Primo enim, quia reliquarum rerum etiam viliorum inventionem ac progrssum solemus solicite investigare, curae pretium putavi futurum, si eius artis historiam quoque persciberem, cui debemus quicquid in reliquis artibus recte distincteque intelligimus. Et quia videbam, doctorum in certa aliqua facultate virorum imagines solere amari ab eius facultatis studiosis, dignos credidi etiam eos, qui omnium facultatum ac disciplinarum magistram ac rectricem in usum humanarum cogitationum vel invenissent vel promovissent, vel denique etiam id tantum conati essent honestissimo propositio, ut in hac chronologia tabula, velut consignata ipsorum ingenia et nomina logicae studiosis suspicienda et colenda proponerentur. Certum enim est eos optime de humano genere mereri, qui eam artem vel inveniunt, vel excolunt, per quam iuvatur ac dirigitur ratio, intellectus, cogitationes, sine quibus ne homines quidem essemus" (ibidem, s. 168-169). 
tym malowidle, ponieważ opisałem ich sobie przed oczami za pomocą obrazów, nawet jeśli niezbyt umiejętnych. ${ }^{40}$

Źródłem owej iucunda voluptas było zapewne obcowanie z twórcami uznanymi za autorytety $\mathrm{w}$ dziedzinie logiki. Kontakt $\mathrm{z}$ ich pismami, a następnie opracowanie dziejów tej dyscypliny, ożywiły ideę uobecnienia poprzez tekst ${ }^{41}$, utwierdzającą przekonanie o możliwości przywołania rzeczywistej obecności danego autora w chwili lektury jego dzieł.

Historia gromadząca wiedzę o przeszłości uchodzi za skarbnicę przykładów określonych postaw i zachowań ludzkich. W przeświadczeniu Keckermanna może ona również dostarczać cenne exempla miłośnikom logiki, odwołującym się do osiągnięć swoich poprzedników i czerpiącym z ich pism zachętę do wytrwałego i systematycznego zgłębiania trudnej sztuki rozumowania ${ }^{42}$. Jej nauka wielokrotnie wiąże się z podążaniem za śladami mistrzów, którzy wyznaczyli nowe ścieżki myślenia, dla wielu niedostępne i praktycznie nieosiągalne bez pomocnej dłoni przewodników. Przygotowana przez gdańskiego humanistę historia logiki ma, w jego założeniu, stanowić pomoc dydaktyczną dla uczniów i studen-

40 „Me etiam, ut vere dicam, iucunda aliqua voluptate perfundere volui, quod tum feci, cum praestantissima ingenia et cogitationum humanarum magistros, ita mihi descripsi ante oculos et picturis hisce si non artificiosis at saltem qualibus, qualibus coloribus adumbratos in hac tabula sum contemplatus" (ibidem, s. 169).

${ }_{41}$ Zob. J. Domański, Tekst jako uobecnienie. Szkic z dziejów myśli o piśmie i książce, Warszawa 1992.

42 Por. „Quae res servire potest multis logicae artis admiratoribus, ut horum tantorum et tam multorum praestantissimorum ingeniorum, quae sibi minime satisfacere potuerunt, ni aliquid in ea quoque disciplina, quae ingenio et acumini peculiariter destinata est, elaborarent exemplo ad logicam suo quoque ingenio iuvandam excitentur. Sed et ille fructus inde percipi potest, quod studiosi logicae delectum hinc ex tanto logicorum numero possint sumere eorum, quos praecipue velint legere et mediocriter saltem scire, quid et quantum cuique tribuere debeant, cum vident quid et quale $a b$ unoquoque sit scriptum. Denique et ea mihi causa fuit inter praecipuas, quod non existimarem bona conscientia mea dissimulari posse aut reticeri, vel unius nomen ex iis quorum cogitationibus atque opera fuissem quali quali tandem momento in eius Systematis logici, cuius editionem paro, constructione adiutus, quapropter quod autores reliqui initio librorum suorum facere solent, ut eorum nomina, a quibus adiuti sunt in conscribendo opera diligenter consignent, id ego plures parietes una fidelia dealbaturus hic potius duxi, quam in vestibulo Systematis mei faciendum. Nunc tempus monet, ut reliquas praecognitorum nostrorum partes persequamur" (Praecognitorum logicorum..., s. 169-170). 
tów tej sztuki, którzy po zapoznaniu się z dziełem będą mogli samodzielnie wybierać traktaty logicznie zgodne z swoimi zainteresowaniami po uprzedniej ocenie ich wartości merytorycznej, kształtowanej w dużej mierze przez twórcę Praecognita logica... Jako ostatnią przyczynę, która skłoniła gdańszczanina do napisania historii logiki, wymienia on swoją pracę nad przygotowaniem traktatu Systema logicae..., oznaczającą de facto wiele godzin spędzonych na lekturze najważniejszych rozpraw z logiki, począwszy od pism logicznych Arystotelesa. Co ciekawe, ten wysiłek badawczy zostaje zilustrowany poprzez obraz wznoszenia potężnego gmachu o przemyślanej niemal w każdym szczególe konstrukcji. Tertium comparationis jest tutaj oczywiste. Systema (a zatem 'system', 'układ', 'kolekcja') posiada wiele cech wspólnych z budowlą, lecz na plan pierwszy wysuwa się starannie zaplanowany układ i dążenie do uporządkowania przestrzeni przez jej odpowiedni podział. W tej konfiguracji historia logiki wraz z tekstem, którego znaczną część stanowi, zostaje usytuowana w przedsionku gmachu Systema...

Narracja historyczna o logice stwarza dla jej twórcy zasadniczo dwie możliwości w przypadku rekonstrukcji poszczególnych wykorzystanych przez Keckermanna faktów. Dzięki przyjęciu określonej perspektywy oglądu przeszłości danej dyscypliny daje ona szansę na ugruntowanie określonej tradycji, z którą autor czuje się szczególnie związany intelektualnie. Tendencja ta przejawia się chociażby w odpowiedniej selekcji faktów i sposobie ich prezentacji. Skoro tak, to opowieść o historii pozostawia równocześnie wolną przestrzeń dla polemiki z poglądami uznawanymi za błędne.

Przed przystąpieniem od omówienia wybranych aspektów diachronicznego ujęcia logiki, ukazującego jej zmienność w czasie i rozwój, kilka uwag ogólnych. Na podstawie stwierdzenia Keckermanna ${ }^{43}$, że nie ma na świecie niczego, co od swego powstania byłoby od razu doskonałe, można przypuszczać, że podzielał on pogląd dotyczący stopniowego procesu doskonalenia się danej rzeczy wraz z upływem czasu. Prawidłowość ta dotyczy również logiki, która nieustannie się zmienia dzięki

43 Por. „Recte quaeris de inventione praeceptorum, ipsam enim artem sive habitum, qui ex praeceptis acquiritur, nemo proprie dici potest invenisse, ideoque cum de logicae inventoribus quaeritur, non intelligitur ipsa ars proprie dicta, sed praecepta pro arte. Deducam autem inventores (sub quibus etiam auctores comprehenduntur) a prima origine. Nihil enim in mundo unquam per homines simul caepit et perfectum est uno momento" (ibidem, s. 65). 
nowym koncepcjom lub innowacyjnym (re)interpretacjom pojęciowego dorobku minionych pokoleń. Jeśli chodzi o sposób konstruowania narracji historycznej, ukazującej koleje dyscypliny logicznej, to trzeba powiedzieć, że opowieść o dziejach logiki posiada rygorystycznie jednolitą strukturę, w której wszelki element narracyjny zostaje okiełznany przez niemal schematyczny zapis poszczególnych faktów składających się na historię rozpatrywanej ars. Schemat opisu pojedynczego wydarzenia z punktu widzenia przeszłości logiki ogranicza się do podania imienia i nazwiska danego logika (czasem z podstawowymi danymi na temat jego życia) wraz z wymienieniem tytułów najważniejszych traktatów logicznych, któremu rzadko towarzyszy ich dłuższe opracowanie. Wszystko to sprawia, że mówienie o narracji historycznej w odniesieniu do tego katalogu wybranych dzieł z logiki staje się niekiedy terminologicznym nadużyciem.

Keckermann kilkakrotnie określa prezentowaną historię logiki mianem chronologii. Perspektywa temporalna zajmuje w tej rekonstrukcji dziejów dyscypliny logicznej rzeczywiście uprzywilejowaną pozycję, chociaż daty i inne określenia czasowe występują w niej jedynie sporadycznie. Historia ta dzieli się na dwa okresy, a arbitralność tego podziału usprawiedliwia po części tok wykładu i pragnienie autora, by szczególnie uważnie skupić się na szesnastym stuleciu. Pierwsza część owej narracji historycznej obejmuje czasy od początku świata aż do XV wieku (wyliczenie logików otwiera biblijny Adam oraz Patriarchowie, a zamyka postać i działalność Girolama Savonaroli (1452-1498), słynnego reformatora religijnego z Florencji ${ }^{44}$. Stulecie szesnaste rozpoczyna się w Keckermannowej historii logiki od ukazania się dzieła

44 Por. „Venio ad Hieronymum Savonarolam, magnum sine controversia virum, celsum theologum, celsum philosophum, qui anno 1499 a Pontifice Romano ob vitae et doctrinae puritatem exustus est, cuius ego libros De veritate fide quattuor, quos scripsit, ut et Meditationes in Psalmum 51, quoties lego, toties mihi iam eo saeculo renascentis doctrinae caelestis et ex Antichristi imposturis emergentis certissima indicia videor agnoscere et caelestis ignis non parvas stricturas. Epitomen scripsit philosophiae, plenam laudis et admirationis. In hac Organi Aristotelici praecepta ita dextre tum contraxit, tum illustravit explicationibus, ut haud sciam an absolutius aliquod Organi compendium optari possit. Atque hic quidem in tanto viro ea saecula concludimus, quae hoc nostrum antecesserunt et porro huius saeculi logicis illustrioribus sequentia aliquot capita destinamus" (ibidem, s. 97-98). 
magistra artium i profesora teologii w Erfurcie, Jodoka Trutfettera ${ }^{45}$, pod tytułem Summulae totius logicae (Erfurt 1501) ${ }^{46}$. Ostatnią zaś postacią, jaką z nazwiska wymienia autor Praecognita logica..., jest jego przyjaciel, Clemens Timpler $(1563-1624)^{47}$ ze Steinfurtu ${ }^{48}$. Wyraźną cezurą w szesnastowiecznych dziejach logiki pozostaje rok 1543, w którym ukazały się dwa, wspomniane powyżej, traktaty Piotra Ramusa (Dialecticae partitiones, sive institutiones... oraz Aristotelicae animadversiones...), wzbudzające niekończące się spory i polemiki wśród logików, a także rozpętujące burzliwą dyskusję nad metodą.

Postulat domagający się od historyka stworzenia całościowego obrazu przeszłości prowadzi do narracji historycznej uwzględniającej porządek czasowy sięgający do bezwzględnego początku - powstania świata. Formuła ab origine mundi — tożsama z frazą ab origine hominis, gdyż początek świata jako fakt jest w tej wizji historii wiązany z naro-

45 Por. H. Lagerlund, Modal syllogistics in the Middle Ages, Leiden 2000, s. 203-204.

46 Por. "Quod ergo ad primam decada attinet, eius anno statim primo editum est Erfordiae opus logicum, quod autor Iodocus Trutueturus Opus mains, sive summam totius logicae inscripsit, dignum profecto quod catalogo logico insereretur, quia etsi lateat obscurum paucisque visum, summo tamen labore et industria ex omnibus scholasticis, tam Thomistis, quam Scotistis est digestum, saepe etiam tabellis adornatum. Ego eum inde usum percepi, quod molestissimo labore legendorum scholasticorum logicorum sim levatus et in hoc velut claro speculo omnes conatus, omne ingenium atque acumen logicum scholasticorum potuerim contemplari. Quicquid enim illi unquam in logicis excuderunt et enixi sunt, illud omne autor in hoc volumen satis profecto magnum alias et densum, solicite sua quadam methodo comportavit, pro quo profecto sua, quantam meruit, gloria non erat defraudandus" (Praecognitorum logicorum..., s. 98-99).

47 Por. J. S. Freedman, European Academic Philosophy in the Late Sixteenth and Early Seventeenth Centuries the Life, Significance and Philosophy of Clemens Timpler (1563/41624), Hildesheim 1985; Id., Aristotelianism and Humanism in Late Reformation German Philosophy: The Case of Clemens Timpler, 1563/64-1624, w: The Harvest of Humanism in Central Europe: essays in honor L. W. Spitz, ed. M. P. Fleischer, St. Louis 1992, s. 213-232. Zob. także A. Aduszkiewicz, Od scholastyki do ontologii: dwa studia, Warszawa 1995, s. 80-82.

48 Por. „Vivit in illustri schola Steinfurtensi vir sane doctissimus, M. Clemens Timplerus, amicus meus, magna observantia colendus, qui et ipse Organon Aristotelis in elegantem epitomen redegit et compendium logicae in Academia Heidelbergensi privatim praelegit, quod nobis ad pleniorem et exactiorem artis methodum constituendam et stimulum addidit et adminiculum suppeditavit" (Praecognitorum logicorum..., s. 168). 
dzinami człowieka — odwołuje się do konkretnego sposobu myślenia o przeszłości. Stworzenie świata, które zgodnie z historiozoficznymi poglądami św. Augustyna dokonało się poza czasem, ale czas powstał wraz z nim („non est mundus factus in tempore, sed cum tempore”) ${ }^{49}$, to rodzaj archifaktu, gdyż oznacza wejście w porządek, przynajmniej z perspektywy Stwórcy, następujących po sobie kolejno zdarzeń. Odkrywcą logiki, jak i również wszystkich pozostałych dyscyplin, jest dla Keckermanna Duch Święty ${ }^{50}$, który następnie posługuje się ludźmi jak instrumentami, by obdarzyć ich poznaniem. Pierwszymi logikami okazują się Adam i Patriarchowie ${ }^{51}$ na czele z Mojżeszem ${ }^{52}$ i Salomonem, „największym królem, obserwatorem szczególnie świata naturalnego i niezwykłym uczestnikiem dyskusji na temat najbardziej skomplikowanych zagadnień" ${ }^{53}$. Włączenie postaci ze Starego Testamentu w obręb rekonstrukcji dziejów logiki wynikało z przyjmowanego bez żadnych zastrzeżeń założenia o prawdziwości Historii Świętej (historia sacra), spisanej pod natchnieniem Ducha Świętego i będącej zarazem wzorcową

49 Por. Aug. De civitate Dei, XI. 6: „Cum igitur Deus, in cuius aeternitatem nulla est omnino mutatio, creator sit temporum et ordinator. [...] procul dubio non est mundus factus in tempore, sed cum tempore". Zob. też: M. L. Lamb, Eternity Creates and Redeems Time: A Key to Augustine's Confessions within a Theology of History, w: Divine Creation in Ancient, Medieval, and Early Modern Thought: Essays Presented to the Rev'd Dr Robert D. Crouse, ed. M. Treschow, W. Otten, W. Hannam, Leiden 2007, s. $117-140$.

50 Por. „Spiritus Sanctus, ut omnium disciplinarum et artium, ita etiam huius praestantissimae primus est principalissimus inventor, qui hominibus postea usus est tamquam instrumentis" (Praecognitorum logicorum..., s. 65).

51 Por. „Primos generis humani parentes et Patriarchas non dubito cum reliquis disciplinis etiam hanc suis posteris tradidisse, praesertim cum origini omnium rerum propiores, tanto praestantiorem intellectum habuerint nostro ingenio atque intellectu, quanto et vitae diuturnitate et valetudinis firmitate et denique aeris, victus ac rerum omnium e terra nascentium praestantia nobis, supra quam credi potest, fuerunt feliciores" (ibidem, s. 65-66).

52 „Mosi imprimis non poenitendam logicorum praeceptorum inventionem et auctionem, quis tribuere possit ex eo, quod Act. 7 dicatur „eruditus fuisse in omnibus disciplinis Aegyptiorum" et quod Iosepho Aegypti, illo magno principe rectissime quis dixerit, qui anno mundi circiter 2229 vixit" (ibidem, s. 66).

53 Por. „Salomon, rex maximus, contemplator rerum praesertim physicarum et admirabilis disputator acutissimarum quaestionum cum Tyriis et cum regina Aethiopiae. Unde dubium non est, logicum etiam fuisse et praecepta multa disputandi et contemplandi vel ab aliis accepisse, vel pro se divini instinctus peculiari auxilio invenisse" (ibidem, s. 67). 
opowieścią ab origine mundi. Nic zatem dziwnego, że ojców logiki poszukuje Keckermann na kartach Pisma Świętego i łączy ich z postaciami wybitnych mężów Bożych.

Właściwymi twórcami dyscypliny logicznej są, zdaniem autora Praecognita logica..., Grecy, „najbardziej utalentowany naród” (gens ingeniosissima), „zajmujący się wszystkimi naukami” („doctrinae omnis cultrix") ${ }^{54}$. Omawiając poszczególnych myślicieli greckich, jacy wnieśli istotny wkład w rozwój logiki, Keckermann podzielił ich na określone szkoły (sectae). Postacią, której poświęca najwięcej uwagi i pod adresem której kieruje najwyższe słowa podziwu jest oczywiście Arystoteles, chociaż wynalezienie logiki przypisuje, podążając zresztą za opinią Stagiryty, Sokratesowi, posługującemu się w swoich rozmyślaniach dwiema ściśle logicznymi umiejętnościami, tworzeniem definicji oraz indukcją ${ }^{55}$. Mistrz Platona staje się tym samym twórcą logiką, ale tylko na zasadzie synekdochy typu: całość zamiast części („synecdoche totius pro parte”). Odkrywcą ars ratiocinandi $\mathrm{w}$ sensie literalnym, a nie figuratywnym, określanym za pomocą tropu, pozostaje, rzecz jasna, tylko Arystoteles. Keckermann usiłuje sine ira et studio ocenić dorobek Platona na polu logiki. Wskazuje zatem na problematykę logiczną, podejmowaną przez niego w niektórych dialogach ${ }^{56}$, ale zarzuca mu, że nie uporządkował swoich poglądów i nie przedstawił ich w postaci metodycznie zorganizowanego systemu. Ten bowiem stał się dopiero dziełem jego ucznia:

54 Por. „De reliquis gentibus orientalibus, Phaenicibus, Aegyptiis, Indis, hoc etiam constat, sapientiae laude excelluisse, sed his in omni disciplinarum successerunt Graeci, gens ingeniosissima, si ulla alia et doctrinae omnis cultrix, seria valde et vel hoc solo constans. In hac ergo quomodo logica praecepta adinuenta et aucta propagataque sint, videndum” (ibidem, s. 68).

55 Por. „Sequitur secta Socratica et Platonica veteris scilicet et purioris Academiae, cuius caput Socrates etsi omnium universalium et non practicarum rerum derisor voluit videri, fuit tamen logicorum praeceptorum studiosus. Unde ei Aristoteles (Met. c. 4.) merito ait tribui inventionem duorum: 1. artificii definiendi, 2. inductionis. Et Galenus initio De sectis philosophicis Socrati tribuit inventionem ethicae et logicae, non quod totum aliquod systema logicum adornarit, sed quod non contemnenda ad id contulerit praecepta, est ergo synecdoche totius pro parte" (ibidem, s. 69).

56 Por. „Socratis discipulus Plato in logicis praeceptis non parum elaboravit, idcirco in dialogis variis logica immiscet, ut in Parmenide de caussis et effectis, item de comparatis; in Sophista et Politico, de toto et partibus; in Philebo et Phaedro, de definitione et divisione. Sed hoc vitii habet Platonica disciplina, quod nihil ordinate docet, quod nullum ullius disciplinae systema integra methodo conformat, quod omnia quasi $\dot{\varepsilon} v$

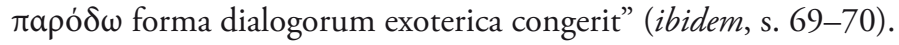


Powiadamy więc, że prawdą jest, iż Bóg zechciał obdarzyć tą chwałą i zaszczytem jedynie szkołę perypatetycką, że to, co Platon i inni przekazali bezładnie, bez metody i porządku, połowicznie, niedoskonale z powodu ozdób retorycznych w postaci metafor i mitów, zawile, to Arystoteles, cud natury, twórca szkoły perypatetyckiej, przekazał jako pierwszy rodzajowi ludzkiemu właściwie pod postacią metody, w sposób uporządkowany, wyczerpujący, jeśli chodzi o wszystkie dziedziny, to znaczy, że dzięki boskiej umiejętności stworzył system nie tylko logiki, ale także pozostałej filozofii, uporządkowany, metodyczny, akroamatyczny i przygotowany na użytek ludzkiego umysłu. ${ }^{57}$

Arystoteles nie tyle odkrywa logikę, ile nadaje jej od samego początku najdoskonalszą, w przekonaniu Keckermanna, postać. Dzięki konsekwentnie stosowanej metodzie udało mu się także drobiazgowo opracować system logiki (wybudować dla niej odpowiednią siedzibę, mówiąc słowami gdańskiego profesora) ${ }^{58}$, a także poszczególnych dziedzin wiedzy. Sztuka rozumowania, której reguły wyłożył Stagiryta w pismach logicznych tworzących Organon, stanowi zwieńczenie nie tylko filozoficznej myśli filozofów podziwianej przez humanistów starożytności, lecz także wyznacza niemal uniwersalny punkt odniesienia dla wszystkich późniejszych logików. Dalsze dzieje dyscypliny logicznej można odtąd ujmować jako historię komentarzy do logiki Arystotelesa, rozciągających się od prostej eksplikacji przez interpretację rozwijającą niektóre z tez zaledwie naszkicowanych aż do radykalnej krytyki pro-

57 „Dicamus ergo quod verum est, solam peripateticam sectam Deum hac gloria et honore dignari voluisse, ut quae Plato et alii confuse, sine methodo et ordine, semiplena, imperfecta per flosculos metaphorarum et fabularum involucra tradidissent, ea Aristoteles, naturae miraculum et autor peripateticae familiae prim humano generi traderet sub forma methodi dextrae, regulatae et quoad partes omnes plenae, id est, ut cum logicae, tum philosophiae reliquae ordinata, methodica, acroamatica atque ad intellectus humani usum informata systemata divino artificio conformaret" (ibidem, s. 73-74).

58 Por. „Nimis profecto lividum hoc est a lateribus, quibusdam trabibus et tegulis logicis ab Academicis forte ac Stoicis comportatis, velle probare, domum logicam non esse $\mathrm{ab}$ Aristotele primitus constructam. Certe sicut qui lateres, calcem et trabes forte aliquot quod ad domum construendam comportant, non dicuntur domum construxisse, ita nec logicum systema formasse, qui indigesta quaedam Aristoteli reliquerunt praecepta. Quare cum aliud adferri non possit, relinquatur logicae inventae honos Aristoteli, quo hominem ethnicum visum Deo fuit certo consilio exornare, inventae in quam et constructae logicae, si non quoad graduum, saltem partium perfectionem. Nobis hoc imprimis dolendum, quod integram non habemus, qualem Aristoteles construxerat" (ibidem, s. 74-75). 
ponującej przezwyciężenie wyjściowego modelu - logiki traktowanej jako doskonałą pod względem materialnym (z uwagi na różnorodność i złożoność problemów, które zostały na jej gruncie wyjaśnione) oraz formalnym (dzięki porządkującej i uniwersalnej metodzie).

Wśród logików wymienia również Keckermann św. Augustyna, św. Hieronima oraz św. Jana Chryzostoma (choć nie poświęca mu większej uwagi). Przypomina niektóre fakty z życia biskupa Hippony potwierdzające jego zainteresowanie logiką. Św. Augustyn (354-430), „najznakomitszy spośród wszystkich teologów w czasach po Apostołach” („omnium post Apostolorum tempora theologorum praestantissimus") ${ }^{59}$, był bowiem również wielkim logikiem, zgodnie z zasadą głoszącą, że nikt nie może być dobrym teologiem, jeśli najpierw nie jest doskonałym znawcą sztuki rozumowania („nemo enim unquam magnus theologus, cui logica non est magna"). Jako zaledwie dwudziestoletni młodzieniec św. Augustyn miał prowadzić publiczne wykłady na temat Kategorii Arystotelesa. W polemice z gramatykiem Kreskoniuszem (Contra Cresconium grammaticum), nieprzyjacielem logiki, bronił ars ratiocinandi, wypowiadając się o niej z największymi pochwałami. Uwagi o św. Hieronimie $^{60}$ jako logiku ograniczają się do fragmentu z jego komentarza do Księgi Ezechiela, w którym stwierdza, że tylko logika może zdemaskować błędne sądy i wykazać ich fałszywość, jakby „za pomocą ognia obrócić je w proch i popiół” (,instar incedii in cineres favillas-

59 Por. „Circa haec ergo tempora vixit magnus ille Aurelius Augustinus Hipponensis in Africa episcopus. Is ut omnium post Apostolorum tempora theologorum praestantissimus habetur, ita logicus etiam (nemo enim unquam megnus theologus, cui logica non est magna) fuit praestans profecto et excellens. Vis 20. annorum iuvenis Aristotelis Categorias exposuit publice, nec unquam tota sua vita logicam desiit magnifacere. Hinc passim multa logica praecepta inspergit, passim logicam laudibus depraedicat summis, imprimis in libro contra Cresconium Grammaticum, logicae (ut plerumque grammatici esse consueverunt), hostem. Libri eius, in quibus praecipue logica eius eruditio conspicua est, sunt: 4 . de doctrina christiana, 3 de ordine, 4 ad Cresconium grammaticum, 3 contra academicos, unus de stoicis et epicureis, de categoriis, unicus de septem artibus liberalibus" (ibidem, s. 81).

60 Por. „Floruerunt eodem tempore magni alii theologi, Hieronymus et Chrysostomus, quorum ille quanti logicam fecerit, si non aliunde, certe ex solis commentariis in caput 25. Exechielis, ubi magnifice admodum (ut solet de omnibus rebus laudatis) de dialectica loquitur, quod nimirum quidquid est falsi, etiam quod putetur robustissimum, dialectica arte subvertatur et instar incedii in cineres favillasque dissolvatur, ut probetur esse nihilum, quod putabatur fortissimum" (ibidem, s. 81-82). 
que dissolvatur"). Eksponowanie gruntownej znajomości logiki przez czołowych Ojców Kościoła wynikało bezpośrednio z bezdyskusyjnie akceptowanego przeświadczenia o istnieniu ścisłego związku między teologią a logiką. Włączenie św. Augustyna i św. Hieronima w poczet logików było jednocześnie wyraźnym wskazaniem źródeł, do których mogą odwoływać się uczestnicy licznych dyskusji religijnych w czasach Keckermanna. To właśnie one miały, między innymi ${ }^{61}$, przyspieszyć wzrost zainteresowania logiką w szesnastym stuleciu. Biskup Hippony stawał się tutaj autorytetem nie tylko teologicznym, lecz także logicznym w niczym nieustępującym perypatetykom.

W rekonstrukcji dziejów logiki w czasach średniowiecza warto zatrzymać się przy postaci Rajmunda Lulla (Ramon Llull, Raimundus Lullus, ok. 1232-1315), zwanego Doctor Illuminatus. Obszerne, w porównaniu z innymi logikami „wieków średnich”, takimi jak chociażby Piotr Abelard czy św. Tomasz z Akwinu, omówienie koncepcji Lulla świadczy o młodzieńczej fascynacji gdańszczanina doktryną stworzoną przez tego katalońskiego teologa. Jego systematyczne aspiracje i pragnienie uporządkowania dotychczasowej wiedzy musiało przez pewien czas współgrać z intelektualnymi oczekiwaniami i ambicjami młodego studenta z Gdańska, który nie zdążył jeszcze wystarczająco przyswoić sobie arystotelizmu, a także rozpoznać w nim systemu godnego pilniejszej uwagi. Zamysł „Oświeconego Doktora”, by wprowadzić porządek do filozofii i teologii, atrakcyjny intelektualnie w sferze postulatów, okazał się w sposobie realizacji niemożliwy do przyjęcia przez Keckermanna. Brak metody złożonej ze zbioru logicznych pryncypiów doprowadził w efekcie do zatarcia granic między poszczególnymi dyscyplinami. Inspirowana alchemią logika została w tej koncepcji przeistoczona (transubstantiare) w metafizykę zajmującą się badaniem bytu jako bytu („tractare de ente qua ens” ${ }^{62}$. W jej obrębie znalazły się także

${ }_{61}$ Por. D. Facca, op. cit., s. 64-71.

62 Por. „Accedit altera ratio, quod cum pro omni habitu acquirendo methodus requiratur sive systema praeceptorum certis conditionibus praeditum, quas infra enumerabimus. Ars Lulli nullam ex boni systematis obtineat proprietatem. Finem artis suae praesigit scientiam, hanc ait per logicam acquiri quatenus particluaria scientiarum principia in generalibus logicae principiis relucent, quod perinde est ac si diceret logicam tractare de ente qua ens et de generalibus entis affectionibus. Id quod eum voluisse, id est, alchimistica quadam artem logicam in metaphysicam transubstantiare, testantur principia logicae, quae ponit" (Praecognitorum logicorum..., s. 92). 
zagadnienia przynależące tradycyjnie do etyki i teologii. W dziele Ars magna Lull przedstawił sposób uporządkowania wiedzy, który, referując za Keckermannem ${ }^{63}$, polega na określeniu zbioru najważniejszych pojęć teologicznych i filozoficznych, głównie z zakresu metafizyki i etyki, utworzeniu alfabetycznie ułożonych komórek (camerae) gromadzących określenia rozmaitych relacji między nimi ${ }^{64}$, a następnie — generowaniu nowych konfiguracji wyjściowych terminów na podstawie tych dwóch zbiorów. Formalizacji tego typu przeciwstawia Keckermann stwierdzenie Arystotelesa, że niemożliwe jest stworzenie takiej dyscypliny, która obejmowałaby problematykę wielu artes, gdyż każda z nich posiada własny przedmiot, metodę i cel, wyznaczający zarazem zestaw podstawowych pojęć. Wobec tego „owa ogólna dyscyplina kompilacyjna” („illa compilatoria disciplina”) nie może niczego uporządkować ani metodycznie opisać.

Jednym z logików zamykających pierwsze okres dziejów dyscypliny logicznej jest Rudolf Agricola (Rodolphus Agricola Phrisius, 14441485), „ta nieśmiertelna ozdoba obydwu Germanii”65 („illud utriusque

63 Por. „Fuit omnino hic scopus Lulli in Arte Magna, ut omnium disciplinarum, imprimis methaphysicae, ethicae, theologiae summos ac generalissimos terminos ex propriis disciplinis translatos in quoddam corpus commune compingeret, eorum similitudines, dissimilitudines affectionesque ad se invicem certis alphabetariis cameris doceret atque ita lectoris rudis animum magnam quadam spe erigeret in vanum, quasi unam iam artem magnam haberet, qua sola cognita posset laborem defugere reliquas disciplinas magno labore discendi. Sed vanus iste omnis est et inanis labor. Etenim ut praeclare Aristoteles docet, impossibile est dari aliquam talem disciplinam, quae id praestet una et sola, quod singulae et omnes per se praestant separatim. Nimirum quaelibet disciplina suum habet determinatum obiectum, sua principia, suum finem et pro hoc fine determinato terminos determinatissimos, quibus perruptis, confusis, alio translatis (sive ea translatio ad generalem, sive ad specialem fiat disciplinam), necesse est fines ipsos disciplinarum confundi de genere in genus transitum turpissimum fieri, omnia reddi indeterminata, infinita, confusa, denique nihil esse ordinatum et methodicum. Imo illa ipsa compilatoria disciplina generalis nullo poterit ordine aut methodo disponi [...]" (ibidem, s. 93-94).

${ }^{64}$ Zob. A. Bonner, The art and logic of Ramon Llull: a user's guide, Leiden 2007, s. 32-33.

65 Rzymska prowincja Germania była podzielona administracyjnie na dwa regiony: Germania Inferior (Dolna Germania), obejmująca tereny położone na lewym brzegu Renu, to jest ziemie dzisiejszej Belgii, Luksemburga i południowo-zachodniej Holandii, oraz Germania Superior (Górna Germania) ze stolicą w Moguncji (Moguntiacum). Pojęcia Germania zaczęto z czasem używać w odniesieniu do ziem leżących na wschód 
Germaniae immortalae decus") ${ }^{66}$, wykładowca greki na Uniwersytecie w Heidelbergu, którego dzieło De inventione dialectica ${ }^{67}$ odegrało ważną rolę we wczesnonowożytnych dyskusjach nad dialektyką, dotyczących zwłaszcza jej związków z retoryką. I chociaż Keckermann zapewnia o wielkiej wartości poznawczej traktatu Agricoli, to nie może milczeniem pominąć faktu, że podążając za Cyceronem w rozważaniach nad logiką, autor więcej miejsca poświęca zagadnieniom związanym ze sztuką wymowy niż ars ratiocinandi. Wybór przewodnika, niewłaściwego, zdaje się sugerować Keckermann, albowiem powinien być nim Arystoteles, w analizie kluczowego dla obu artes pojęcia inwencji, nie mógł doprowadzić do precyzyjnego, by nie powiedzieć metodycznego, opisania przynajmniej jednej z nich.

Sa eculum logicorum

Wiek szesnasty pod względem liczby logików i ich rozpraw stanowi doskonałą przeciwwagę dla wszystkich wcześniej omówionych autorów ${ }^{68}$. Keckermann określa to wyjątkowe ożywienie w badaniach nad logiką, ich wielokierunkowość i różnorodność, w następujący sposób:

Od początku świata nie było tak żądnego logiki stulecia, w którym by wydano tak wiele książek z logiki, a studia logiczne kwitty bardziej, niż to stulecie od

od Renu i północ od Dunaju. Rudolf Agricola pochodził z Fryzji, jednej z prowincji obecnej Holandii, a zatem można powiedzieć, że wywodził się z Dolnej Germanii.

66 Por. „Eodem saeculo, anno nimirum Christi 1450, floruit illud utriusque Germaniae immortale decus, Rodolophus Agricola, vetustissimae huius Academiae professor, cuius fama aeternitati consecrata aetatem feret longiorem, quam eius honori erectum monumentum, quod Heidelbergae quotidie intuemur. Edidit is De inventione dialecticae libros tres, quos Iohannes Mattheus Phrisemius doctissimis notis auxit. Hi libri apud omnes semper in admiratione fuerunt et merito quidem, ita ad usum sunt accommodati loci quos tradit. Ciceronem in plerisque secutus est et idcirco rhetoricum finem diligentius intendit, quam vere logicum, tertius liber totus est rhetoricus, de affectibus movendis. Quid ad absolutum systema logicum praeterea desideretur, requisita systematis loquentur" (Praecognitorum logicorum..., s. 97).

67 Por. C. Vasoli, La dialettica e la retorica dell'Umanesimo: 'Invenzione' e 'metodo' nella cultura del XV e XVI secolo, Milano 1968; P. Mack, Renaissance argument: Valla and Agricola in the traditions of rhetoric and dialectic, Leiden 1993.

68 Keckermann wymienia również trzech uczonych mężów, którym należy się największy podziw: „Atque adeo profitentur sese inter omnes nostri aevi viros doctos tres potissimum admirari: inter Germanos Erasmum Roterodamum, inter Gallos Guiliemum Budaeum, inter Hispanos Ludovicum Vivem" (Praecognitorum logicorum..., s. 100). 
narodzin Chrystusa, w którym żyjemy. Jest więc niemożliwe, aby wyliczyć tutaj jeszcze więcej logik czy logików. W ciągu [ostatnich] trzydziestu lat ukazało się tyle książek z logiki, że nawet jeśli widziałem i czytałem ich większą część, to przecież nie mogę ich wymienić, gdyż większości z nich nie mam przy sobie, a przeglądanie lub czytanie tak wielkiej mieszaniny tytułów byłoby w przyszłości dla czytelnika nużące. ${ }^{69}$

XVI stulecie jawi się w świetle powyższego sądu, jak i szczegółowego katalogu nazwisk oraz tytułów najważniejszych traktatów, jako wiek logików. Słowa mówiące o nieprzeliczonej liczbie dzieł logicznych są tylko częściowo usprawiedliwione topiką wstępu, w którym autor tłumaczy niemożność ogarnięcia wszystkich tekstów, wymienienia ich choćby z tytułu, wprowadzając tym samym konieczność selekcji materiału. Odzwierciedlają one także do pewnego stopnia stan faktyczny. Pojawiające się wówczas wciąż nowe traktaty z logiki dają wyobrażenie o toczonych przez najbardziej wpływowych humanistów dyskusjach nad dyscypliną logiczną, jej statusem oraz relacjami z innymi sztukami zajmującymi się słowem (artes sermocinales). W ciągu tych niekończących się polemik krytycznej rewizji podlegała definicja logiki, zakres jej badań, a także sposób ich prowadzenia (kwestia metody i metodyczności). Wszystko to powodowało daleko idące przeobrażenia strukturalno-funkcjonalne tej dyscypliny. Linia tych przemian często rozgałęzia się w nieoczekiwanym miejscu i pewnie dlatego utrudnia ich systematyczne opisanie. Kilka tendencji można jednak spróbować zarysować. Od ogólnie pojętej sztuki rozprawiania (ars disserendi) logika zaczęła ewoluować w kierunku umiejętności dowodzenia i wnioskowania, co pociągało za sobą jeszcze większą formalizację niż dotychczas. Proces ten wspierało jej wyraźne odróżnienie od gramatyki (kwestia etymologii i definicji) oraz retoryki, z którą wielokrotnie wchodziła w niebezpieczne, gdyż zagrażające autonomii każdej z nich, związki. Wymieńmy tylko kilku auto-

69 „Nullum ab inito usque mundi saeculum fuit, vel ita cupidum logicae, vel in quo plures libri logici editi sunt et studia logica magis floruerint, quam hoc est saeculum a nato Christo, in quo vivimus. Itaque hic iam amplius vel logicas vel logicos impossibile est ad numerum revocare. Vel intra annos tredecim tot prodiere logici libelli, ut etiamsi forte eos magna ex parte viderim et legerim, numerare tamen non possim, partim quos eos amplius mecum non habeam, partim quod lectori molestum sit futurum tantam nominum farragionem inspicere aut legere" (ibidem, s. 98). 
rów istotnych w procesie kształtowania się filozofii i koncepcji logiki gdańszczanina.

Jednym z ważniejszych logików przed wystąpieniem Ramusa pozostaje niewątpliwie Filip Melanchton (właśc. Philipp Schwartzerd, 1497-1560), „Feniks Europy” (Europae Phaenix) ${ }^{70}$ oraz „wielka światłość wszelkiej nauki w Niemczech” („magnum omnis doctrinae in Germania lumen"). Melanchton został umieszczony w katalogu logików jako autor traktatu Erotemata dialectices... (46 wydań między rokiem 1547 a 1600$)^{71}$, podręcznika szeroko znanego i komentowanego nie tylko przez humanistów związanych z obozem reformacji. W ujęciu Melanchtona inwencja dialektyczna, a więc wynajdywanie argumentów, została powiązana z nauką o loci communes. Melanchton wyłożył, zdaniem Keckermanna, swój system (systema Philippeum) przy pomocy właściwej metody (methodo decenti), umożliwiającej zachowanie odpowiedniego sposobu nauczania (jak również stylu) o rzeczach szczególnie istotnych dla jego współczesnych.

Rekonstrukcja przeszłości logiki w wieku XVI wyraźnie rozpada się na dwa okresy: usque ad Petrum Ramum oraz a Petri Rami tempore. Momentem przełomowym w dziejach tej dyscypliny jest wobec tego rok 1543, w którym ukazały się wspomniane już tutaj dwukrotnie traktaty Piotra

70 Por. „Anno 1547 ille Europae Phaenix et magnum omnis doctrinae in Germania lumen, Dn. Philippus Melanchthon, Erotematum dialecticarum libri quattuor, iterum atque iterum recognitos Lipsiae edidit et dedicavit Iohanni Camerario, Ioachimi fili, neque enim haec est prima editio, sed certum est, Dn. Philippum primum esse (Caesarium excipio), qui dialecticam ediderit sub reformationem doctrinae Evangelicae. [...] Scripsit ergo logicam Philippus ante Ramum et optandum esset, eum ut tempore, ita etiam dignitate priorem ab omnibus haberi atque antiquiorem. Systema Philippeum methodo decenti dispositum est, plenum etiam, si demonstrationis doctrina atque nonnulla in primo quoque libro addantur, forma docendi et stylus atque exempla nostri aevi ingeniis atque usui accommodatissima, ita ut absolutum exemplar nobis a tanto viro relictum sit systemata disciplinarum ex Aristotele pro nostro saeculo construendi, quod si imitari primum et deinde luce doctrinarum, quae exinde semper maior ac maior effulsit, illustrare libuisset, maiorem certe logicae atque adeo totius philosophiae usum videremus" (ibidem, s. 152-153).

71 Por. P. Mack, A History of Renaissance Rhetoric 1380-1620, Oxford 2011, s. 107108; G. Frank, Philipp Melanchton (1497-1560): Reformer and Philosopher, w: Philosophers of the Renaissance, ed. P. R. Blum, transl. B. McNeil, Washington D. C. 2010, s. $153-155$. 
Ramusa (Pierre de la Rameé, Petrus Ramus, 1515-1572)72, określonego przez Keckermanna mianem „największego Arystarcha spośród wszystkich logików” („ille omnium logicorum maximus Aristarchus”) ${ }^{73}$. O jakiego Arystarcha w tym przypadku chodzi? Czy mowa jest o Arystarchu z Samos, autorze pierwszej teorii heliocentrycznej, czy Arystarchu z Samotraki, dyrektorze Biblioteki Aleksandryjskiej, uznawanym za twórcę krytyki literackiej? A może o jednym i drugim, skoro można wskazać liczne analogie między nimi a francuskim humanistą? Miażdżąca krytyka logiki Arystotelesa z powodu braku metody oraz próba przezwyciężenia systemu filozoficznego Stagiryty, jaka stała się dziełem Ramusa, mogła nasuwać skojarzenia z tak rewolucyjnymi poglądami na budowę wszechświata, jak heliocentryczne koncepcje Arystarcha z Samos, przypomnianymi w dodatku w XVI stuleciu przez Mikołaja Kopernika.

Kontrowersyjne poglądy Ramusa na istotę logiki i jej funkcje szybko spotkały się z falą krytyki. Uważnie odnotował Keckermann pierwsze wystąpienia francuskich humanistów przeciwko doktrynie autora Aristotelicae animadversiones. Przywołuje zatem pisma polemiczne benedyktyna Joachima Périona (Ioachimus Perionius, ok. 1499-1559) ${ }^{74}$,

72 Krytyczny stosunek Keckermanna do logiki i filozofii Ramusa omawia m.in. I. Dąmbska, Logika w gimnazjum akademickim gdańskim XVII wieku, „Rocznik Gdański”, 1957, XV/XVI, s. 199-223. Zob. także B. Nadolski, op. cit., s. 45-47.

73 Por. „Peter Ramus proxime sequitur, ille omnium logicorum maximus Aristarchus, qui alicubi profitetur annis totis viginti sese meditationibus logicis fuisse occupatum, id ergo postulare posse merito, ut logicum monumentum sepulchro suo imponatur, non secus ac Archimedes cylindrum (in quo maxime se exercuerit) voluit imponi suo. Logicam is suam primo edidit anno 1543, sed saniorem logicam quam postea. Primo enim non duos, sed tres ea libros habet et in tertio praecepta de sophisticis elenchis perspicue satis traduntur, qua utilissima parte Rami cogitationes posteriores, logicum corpus misere mutlilarunt occasionemque sectatoribus dederunt vel ingenia studiosae rerum logicarum iuventutis misere excarnificandi, vel praecepta peripateticorum de solvendis sophismatibus clam post sua pulpita, quoties in disputationem eundum est, suppilandi, vel denique errorem fatendi et saluberrimam doctrinam ante inquissime in exilium eiectam exultim recipiendi atque in agrum logicum iterum postliminio restituendi, ut quidem factum a multis, qui cum iactura magna Rameae methodi istam doctrinam suis Rameis logicis agglutinarunt, quod viderent sine iuventutis incommodo non posse omitti. Publice noti sunt, nec est necesse eos a me nominari. Sed de systematae logicae Rameae postea loquentur et iudicabunt canones boni rectique systematis" (Praecognitorum logicorum..., s. 104-105).

74 Por. „Quinquagesimus in ordine illustrium logicorum fuit Petrus Ramus, cui prolixiorem tractatum magnis causis moti impendere voluimus, sequitur quinquagesimus 
w których bronił on zakwestionowanego przez Ramusa autorytetu Arystotelesa w dziedzinie logiki, a także rozprawę Platonis cum Aristotele in universa philosophia comparatio ${ }^{75}$ Jacquesa Charpentiera (Iacobus Carpentarius, 1524-1574) ${ }^{76}$ zawierającą wiele ekskursów dotyczących krytycznego omówienia poglądów Ramusa. Odtwarzając dzieje logiki w okresie wielkich przemian u progu nowożytności, przemian, jakim podlegały zarówno filozofia, jak i logika, Keckermann usiłuje w możliwie jak najbardziej bezstronny sposób oceniać dorobek autorów mających inne niż on przekonania religijne. Benedyktyn Périon jako adwersarz Ramusa może stać się dla gdańskiego humanisty, a także innych perypatetyków, potencjalnym sprzymierzeńcem w obronie Arystotelesa, niemniej Keckermann nie zapomina o tym, że tymczasowy sojusznik jest również autorem traktatu Topicorum theologicorum libri duo (Paryż 1549), w którym zgromadzono toposy teologiczne stosowane w krytyce doktryny ewangelickiej. Walka ze wspólnym wrogiem sprawia, że logika może przynieść chwilowy pokój. Sine ira et studio usiłuje potraktować Keckermann portugalskiego jezuitę, Pedro da Fonseca (Petrus

primus Ioachimus Perionius, Petri Rami adversarius, qui anno statim 1544 Dialecticae libros tres edidit, quos Caelius Curio eruditis commentariis auxit Basileae excusos. Edidit item Ioachimus Perionius anno praecedenti 1543 pro scriptis Aristotelis contra virulentas et iuvenilis intemperantiae plenas Petri Rami Animadversiones, orationes duas apologeticas satis prolixas et lectu dignissimas ob eas controversias, quae de scriptorum Aristotelis vel interitu, vel situ et corruptione solent ab Antiperipatetici moveri. Vertit et Organon Aristotelis, in quo non parum superstitioso illo Latinitatis studio peccatur, ut doctissime ostendunt inter alios Petrus Iohannes Nunnesius in oratione de causis et remediis obscuritatis Aristotelicae et Iohannes Baptista Monlorius, duo clarissimi Hispaniae philosophi. Edidit idem Perionius Topica theologica, in quibus contra Evangelicam doctrinam exempla pene omnia torquet magis declamatorie perfecto, quam dextre aut logice" (ibidem, s. 151-152).

75 Por. E. P. Mahoney, Aristotle and Some Late Medieval and Renaissance Philosophers, w: The Impact of Aristotelianism on Modern Philosophy, ed. R. Pozzo, Washington D. C. 2004, s. 20.

76 Por. „Anno 1573 Iacobus Carpentarius edidit Parisiis collationem Platonis cum Aristotele in universa philosophia, sive potius commenatarios in Alcinoum Platonicum, opus eruditum, quo plurima passim intexuit diggresiones logicas adversus Petrum Ramum. Doctrinam de methodo conatur imprimis vindicare, in qua tamen ipse, si verum fatendum, minime dexter, alias multa habet lectu digna et utilia, modo cum iudicio errores segregentur. Facit idem non semel mentionem suae cuiusdam Epitomes logicae, quam nobis videre nondum contigit" (Praecognitorum logicorum..., s. 176). 
a Fonseca, 1528-1599) ${ }^{77}$, autora obszernego traktatu używanego przez długi czas w kolegiach jezuickich Institutionum dialecticarum (Lizbona 1564). O podręczniku tym wypowiada się z uznaniem, a nawet stwierdza, że nikt ze znanych mu logików tak wyczerpująco nie przedstawił nauki o etymologiach i tworzeniu definicji.

Wśród logików, jacy wywarli największy wpływ na filozofię gdańszczanina, pierwsze miejsce zajmuje związany z Uniwersytetem w Padwie (philosophus Patavinus) Jacopo Zabarella (1532-1589) ${ }^{78}$,twórca kilku ważnych dla interpretacji arystotelizmu rozpraw zebranych w tomie pod tytułem Opera logica, wydanym po raz pierwszy w Wenecji w 1578 roku i dedykowanym królowi Polski, Stefanowi I Batoremu. Traktat włoskiego humanisty o metodzie przyczynił się, dzięki niezwykłej poczytności na uniwersytetach niemieckich, do powstania, w przekonaniu Keckermanna, takiej sytuacji, w której Niemcy w niczym dzisiaj nie ustępują w sztuce logiki Arystotelesowskiej Włochom. Zabarella jest w ujęciu Keckermanna mistrzem szesnastowiecznych perypatetyków i to zarówno jako wnikliwy komentator pism logicznych Stagiryty, jak i ich twórczy interpretator, potrafiący zachować intelektualną niezależność od Arystotelesa nawet wtedy, gdy przejmuje jego słownik pojęciowy.

Próbując nakreślić możliwie szeroką panoramę dziejów logiki w szesnastym stuleciu, Keckermann przywołał nazwiska i tytuły traktatów najważniejszych w jego przeświadczeniu logików. Na podstawie rzetelności,

77 Por. „Anno 1577 Petrus a Fonseca Hispanus edidit Institutionum dialecticarum libros octo, quos Iesuitae suis nunc ubique discipulis proponunt. Doctrinam de rerum nominibus et etymologia tractat plenius quam ullus logicorum, quos vidi. Sed et doctrinam definitionis et divisionis, denique locorum inventionis maximopere ad-

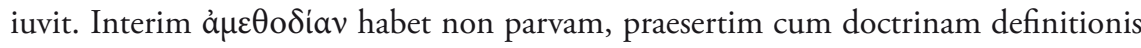
et divisionis tradit post praecepta enuntiationis, in doctrina demonstrationis curtus admodum, non sunt pauca etiam hinc inde omissa et falso praecepta, leges systematis iudicabunt plenius” (ibidem, s. 157).

78 Por. „Eodem anno [scil. 1578] Iacobus Zabarella, philosophus Patavinus, primum edidit libros logicos ob raram in Italo perspicuitatem, amoenam copiam et dispositissimum ordinem suspiciendos. In his eminent illi quattuor de methodis, quibus lumen omnis methodi, ut et demonstrationis, imo praecipuarum logicarum maximum in Germania accendit, sic ut vere dicere possimus, unico Zabarellae deberi, quod Germani hodie Italis in doctrina Aristotelis logica nil velint concedere. [...] Anno 1584 apologiam pro doctrina de methodo contra Franciscum Piccolomineum emisit" (ibidem, s. 158). 
z jaką w zaledwie kilku słowach komentarza usiłuje ocenić te rozprawy logiczne, wywodzące się w dodatku z różnych tradycji myślenia o ars ratiocinandi, można przypuszczać, że większość z tych dzieł faktycznie uważnie czytał lub przynajmniej przeglądał. Jako historyk logiki — i to jeden z pierwszych — jest Keckermann niezmiennie arystotelikiem, który odtwarza dzieje powstania i rozwoju doktryny logicznej wypracowanej przez Stagirytę. Jeśli krytykuje któregoś z omawianych logików (przykładowo Rajmunda Lulla czy Piotra Ramusa), to czyni to niemal zawsze ze stanowiska wczesnonowożytnego arystotelizmu (Cesare Vasoli określa tę formację filozoficzną mianem „nowego arystotelizmu”, il nuovo aristotelismo ${ }^{79}$ ). „Chronologia logiczna”, jaką w efekcie zaprezentował gdański profesor filozofii, daje znakomite wyobrażenie - nawet jeśli nie jest ono pełne, tym bardziej, że w założeniu autora katalog ten nie może być kompletny — o dyskusjach prowadzonych wokół najważniejszych pojęć związanych z logiką (na czele z rozmaicie tematyzowaną kwestią metody). Osią tej rekonstrukcji pozostaje kontrowersja między dwoma sposobami myślenia o logice, reprezentowanymi przez poróżnionych w interpretacji pism logicznych Arystotelesa ramistów i perypatetyków. Jeśli nawet przyjąć, że historia logiki w ujęciu Keckermanna może zostać potraktowana jako rekonstrukcja dziejów sztuki logicznej Stagiryty, uznanej za systematyczną i metodyczną, to i tak nie zmienia to faktu dowartościowania diachronicznego ujęcia danej dyscypliny, które jednoznacznie pokazuje, że nie jest ona spetryfikowanym katalogiem pojęć, ale dynamicznym, choć o zakreślonych granicach, układem powiązanych ze sobą rozmaitymi relacjami idei, negocjowanym i ustanawianym za każdym razem wciąż na nowo.

\section{Divina Magistra Logica. Bartłomiej Keckermann as a Historian of Logic}

The main aim of the paper is to analyze a part of the treatise entitled Praecognitorum logicorum tractatus, written by Bartholomew Keckermann (15721609), in which he attempts to present the history of logic since the creation of the world (ab origine mundi). In Keckermann's philosophy the art of logic is treated as a universal instrument of human cognition. The application of its

79 C. Vasoli, Bartholomeus Keckermann..., s. 240. 
rules is essential in the description of this systematic knowledge. The concept of method plays a crucial role in this context. According to Keckermann, the catalogue of the most important works in logic can be used as a useful reading list. The reconstruction of logical history through the ages involves the enumeration of the most influential logicians and their works. In fact, Keckermann's history of logic puts a special emphasis on Aristotle's logic. Revealing the history of logical discipline, Keckermann proved that it can not be restricted to a relatively limited and immutable set of concepts. On the contrary, it is a dynamic system of ideas, still at the beginning of establishing a new conceptual order. 